\title{
To What Extent Will the Banking Industry be Globalized? A Study of Bank Nationality and Reach in 20 European Nations
}

\author{
Allen N. Berger \\ Board of Governors of the Federal Reserve System \\ Washington, DC 20551 U.S.A. \\ Wharton Financial Institutions Center \\ Philadelphia, PA 19104 U.S.A. \\ aberger@frb.gov \\ Qinglei Dai \\ Norwegian School of Management BI \\ Sandvika, Norway \\ qinglei.dai@bi.no \\ Steven Ongena \\ Tilburg University \\ Tilburg, The Netherlands \\ steven.ongena@kub.nl \\ David C. Smith \\ Board of Governors of the Federal Reserve System \\ Washington, DC 20551 U.S.A. \\ dsmith@frb.gov
}

May 2002

The opinions expressed here do not necessarily reflect those of the Federal Reserve Board or its staff. For helpful suggestions, the authors thank Bob Avery, Mark Carey, Gayle DeLong, Bob DeYoung, Ralf Elsas, Charles Freedman, Ron Giammarino, Charles Goodhart, Leora Klapper, Myron Kwast, Loretta Mester, Dave Nickerson, Stephen Poloz, Alberto Pozzolo, John Rogers, Giorgio Szegö, Greg Udell, Wanda Wallace, Frank Warnock, Barry Williams, Craig Wright, and seminar participants at the Australasian Conference in Finance and Banking, the Conference on Framing Financial Structure in an Information Environment at Queen's University, the University of Lausanne Conference on the Regulation of Banking and Financial Markets, and the College of William and Mary, Federal Reserve Board, Indiana University, University of Frankfurt, University of Ghent, University of Mannheim, WHU Koblenz, and York University. Ongena thanks the Netherlands Organization for Scientific Research (NWO) for research support. David Birks made available the GlobalCash-Europe96 data and Nate Miller provided outstanding research assistance.

Please address correspondence to Allen N. Berger, Mail Stop 153, Federal Reserve Board, 20th and C Streets. NW, Washington, DC 20551, call 202-452-2903, fax 202-452-5295, or email aberger@frb.gov. 


\title{
To What Extent Will the Banking Industry be Globalized? A Study of Bank Nationality and Reach in 20 European Nations
}

\begin{abstract}
$\underline{\text { Abstract }}$
We model two dimensions of bank globalization - bank nationality (a bank from the firm's host nation, its home nation, or a third nation) and bank reach (a global, regional, or local bank) using a two-stage nested multinomial logit model. Our data set includes over 2,000 foreign affiliates of multinational corporations operating in 20 European nations. We find that these firms frequently use host nation banks for cash management services, and that bank reach may be strongly influenced by this choice of bank nationality. Our results suggest limits to the degree of future bank globalization.
\end{abstract}

JEL Classification Numbers: G21, G15, G28, G34

Keywords: Bank, Globalization, Europe, Mergers 


\section{To What Extent Will the Banking Industry be Globalized? A Study of Bank Nationality and Reach in 20 European Nations}

\section{Introduction}

Recent years have seen a drastic reduction in global barriers to competition in the financial services industry. Deregulation around the world has permitted consolidation across more distant and different types of financial institutions. Improvements in information processing, telecommunications, and financial technologies have facilitated greater geographic reach by allowing institutions to manage larger information flows from more locations and to evaluate and manage risks at lower cost without being geographically close to the customer. Moreover, growth in cross-border activities of nonfinancial companies has spurred greater demands for institutions that can provide financial services across borders.

Despite these forces, the financial services industry in general, and the commercial banking industry in particular, currently remain far from globalized. While there has been considerable bank consolidation within individual industrialized nations in recent years, cross-border bank mergers and acquisitions among these nations have generally been much less frequent (Group of Ten 2001). In most other nations as well, market shares of foreign-owned banks are generally below 10\% (Levine 1996).

We argue here that the banking industry may never become fully globalized, even after adjusting to the full effects of deregulation, technological progress, and increased cross-border nonfinancial activity. Some banking services - such as relationship lending to informationally opaque small businesses - may always be provided primarily by small, local institutions headquartered in the nation in which the services are demanded. Other services, such as syndicated loans to large borrowers, are more likely to be provided by large, global institutions for which the home nations of these institutions are of much less consequence to the demanders of the services. In our view, the better question is not when or if the banking industry will be globalized, but rather the extent to which it will be globalized.

To address this question, we examine how more than 2,000 foreign affiliates of large multinational corporations choose a bank for cash management services in each of 20 European nations. The term cash management covers a variety of core banking services, with an emphasis on services that require frequent turnover, including liquidity management, short-term lending, foreign exchange transactions, and assistance with hedging. In effect, cash management refers to virtually all short-term banking needs, and likely requires a physical presence in the nation in which the services are provided.

The provision of cash management services to foreign affiliates of large multinational corporations 
represents a crucial "middle ground" of financial services that could be provided by 1) small banks headquartered in the host nation, 2) global banks headquartered in a few financial centers, but with offices in many nations around the world, or 3) institutions between these two extremes. Moreover, because cash management services to foreign affiliates of large multinational corporations represent a significant portion of the potential market for global banks, they should be influential in determining the extent to which the banking industry will become globalized. To our knowledge, there is no prior research available on the choice of bank for cash management services by these firms.

Europe provides an excellent laboratory for studying the globalization of the banking industry. It has many developed nations that are geographically proximate, virtually no formal regulatory restrictions on crossborder bank entry within the EU, and many large banks. Moreover, substantial variation exists in banking sector size and financial development across European nations. Our sample includes information from nations with large banking sectors and relatively well-developed financial systems (e.g., the U.K. and Germany), nations with smaller banking sectors, but well-developed financial systems (e.g., Austria and Norway), countries with small banking sectors and less-developed financial systems (e.g., Portugal and Greece) and former socialist nations with developing financial systems (e.g., the Czech Republic and Hungary). This variation allows us to test for the effects of banking sector size, financial development, legal structure, and other factors that might influence the extent to which the banking industry becomes globalized.

We identify two distinct dimensions of globalization - bank nationality and bank reach. Bank nationality refers to the location of a bank's headquarters relative to the host nation where the affiliate operates and the affiliate's corporate home. A host nation bank is headquartered in the nation in which the affiliate operates, a home nation bank is headquartered in the same nation as the multinational corporation's headquarters, and a third nation bank is headquartered in neither the host nor the home nation. A foreign affiliate of a multinational corporation may prefer a host nation bank for the "concierge" services that it can provide. That is, a host nation bank should best know the local market, culture, language, and regulatory conditions in the host nation, and have superior information about local nonfinancial suppliers and customers. An affiliate may instead prefer a home nation bank that can offer the "home cookin"" advantages of knowing the market, culture, language, and regulatory conditions of the affiliate's home nation. A home nation bank may also be the bank that serves the headquarters of the corporation and therefore may have an informational advantage in providing services to the 
firm and providing relationship benefits to the corporation as a whole. Alternatively, the firm may choose a third nation bank in circumstances in which neither the concierge benefits of a host nation bank nor the home cookin' benefits of a home nation bank is of great consequence.

Bank reach refers to the geographic scope and size of the chosen bank. A global bank operates in many nations and is among the world's largest institutions, a local bank operates in a single nation, and a regional bank lies between these extremes. Some firms operating in a foreign country may prefer a global bank that offers the broadest range of financial services, expertise within many foreign markets, and the ability to facilitate large deals. Global banks may also provide superior stability because of their risk diversification and/or implicit government protections against closure. Other firms may prefer a local bank that may be more focused on establishing a close relationship with the firm or may be better able to offer specific information about doing business in the local market. Still others may find that the tradeoff between services offered by global and local banks leads them to choose the intermediate reach of a regional bank.

We empirically investigate bank nationality and reach using a two-stage nested multinomial logit model. In the model, firms first choose bank nationality - a host nation bank if the concierge benefits dominate, a home nation bank if the home cookin' benefits dominate, and possibly a third nation bank if neither set of benefits is very important. We assume that this choice depends on host nation characteristics, geographic, cultural, and financial differences between the home and host nations, and attributes of the corporation itself. These variables are designed to reflect both the demand of the firms for cash management services from banks of different nationalities and the willingness and ability of these banks to supply the services. Conditional on bank nationality, firms then select bank reach based on preferences for the range of services, financial stability, relationship services, and local knowledge offered by global, regional, and local banks. We model this decision directly as a function of corporate attributes, but note that within the structural model, the choice also depends indirectly on host nation characteristics and home nation-host nation differences through the determination of bank nationality.

We maintain that bank nationality is of primary importance in the choice of banks by firms operating in foreign countries, and that the choice of bank nationality may have a significant influence on the degree of bank reach. The dependence of bank reach on the choice of bank nationality follows from the simple observation that banks can only expand across international borders to the extent that customers are willing to purchase services from foreign-owned banks. For instance, in an extreme case where all customers preferred host nation banks for 
all services, banks might not cross any borders, and all services may be provided by local banks.

Our approach to examining the extent of bank globalization makes several contributions. First, to our knowledge, this is the first study to examine bank nationality and bank reach together and view these as joint determinants of bank globalization. Bank reach is usually viewed in isolation as measuring bank globalization, but we argue that bank nationality is also important. Second, we provide a set of stylized facts on the choice of bank for cash management services made by the foreign affiliates of large, multinational corporations. These services provided to these firms constitute a significant portion of the potential market for global banking services and lie in the crucial middle ground of financial services that could be provided by banks of virtually any nationality and reach. Third, we investigate some of the potential determinants of bank nationality and reach, including host nation characteristics, home-host nation differences, and attributes of the corporations themselves.

Our investigation yields a number of interesting findings, three of which we briefly preview here. First, we show that foreign affiliates of multinational companies choose host nation banks for cash management services more often than home nation or third nation banks. This result is consistent with concierge benefits dominating home cookin' benefits and may be surprising given that firms might be expected to prefer their home nation banks. Second, we find that bank reach is strongly associated with bank nationality. For example, if a host nation bank is the choice of nationality, then the firm is much less likely to choose a global bank. Third, we find that bank nationality and bank reach both vary significantly with the degree of legal and financial development. For example, firms appear to be much less likely to choose a host nation bank and more likely to choose a global bank when operating in the former socialist nations of Eastern Europe. Overall, our results suggest that the extent of future bank globalization may be significantly limited as many corporations continue to prefer local or regional banks for at least some of their services.

The rest of the paper proceeds as follows. Section 2 reviews previous research on bank nationality and reach. Sections 3 and 4 describe our data set and methodology, respectively. Section 5 presents the findings from our main empirical model and some robustness checks. Section 6 concludes with some implications of the findings and some important caveats.

\section{Related literature on bank nationality and reach}

The extant research on bank nationality has been confined primarily to the study of one component of what we term the home cookin' effect. In particular, previous investigations have found that some banking 
organizations engage in a "follow-your-customer" strategy of setting up offices in nations where their home nation customers have foreign affiliates (e.g., Goldberg and Saunders 1981, Grosse and Goldberg 1991, Ter Wengel 1995, Brealey and Kaplanis 1996). However, more recent work finds that foreign-owned banks lend mostly to borrowers other than customers from the home nation (Seth, Nolle, and Mohanty 1998) and tend to have high proportions of their assets invested in business loans to domestic borrowers (Stanley, Roger, and McManis 1993). These findings suggest that while some banks do follow their customers abroad, this often may not be the dominant motivation behind cross-border expansion.

Along another dimension, researchers have studied how bank nationality influences the ability to provide services. For example, large, foreign-owned banks appear to have problems supplying credit to informationally opaque small businesses (e.g., Berger, Klapper, and Udell 2001, Clarke, Cull, and Martinez Peria 2001). Moreover, foreign-owned banks - that is, home and third nation banks - have sometimes been found to be less efficient on average than host nation banks in developed nations, with the possible exception of U.S. banks operating abroad (e.g., DeYoung and Nolle 1996, Berger, DeYoung, Genay, and Udell 2000).

Much of the prior research on bank reach has focused on cross-border bank consolidation. One general finding is that the reach of banks is not as global as might be expected given the significant reductions in barriers to competition discussed earlier. Cross-border mergers and acquisitions (M\&As) in banking are considerably rarer than in other industries (e.g., Focarelli and Pozzolo 2001a) and, for much of the 1990s, paled in comparison with bank M\&A activity within individual nations, including M\&As in individual European nations (e.g., Berger, Demsetz, and Strahan 1999, Group of Ten 2001). Another general result is that cross-border mergers, when they occur, tend to be relatively unprofitable. Cross-border consolidation began to increase in Europe in the late 1990s. However, the combined bidder and target value increases from these mergers have been generally zero or negative, compared with domestic mergers, where combined values have been positive on average (Beitel and Schiereck 2001). A recent study of domestic and cross-border M\&As involving U.S. banks found more value created by the cross-border M\&As, although the study also found that more concentrated geographic and activity focus had positive effects on value (DeLong 2001).

The low frequency and profitability of cross-border bank consolidation likely reflects some remaining explicit or implicit cross-border barriers. These may include problems in serving informationally opaque small businesses or in operating efficiently abroad, as already discussed. Moreover, recent research on cross-border 
bank M\&As suggests that banks in highly regulated markets are less likely to be acquired and that information costs, as proxied by distance and cultural differences, tend to deter cross-border M\&As (e.g., Buch and DeLong 2001). Finally, a growing body of literature argues that while explicit barriers to cross-border reach within Europe have been removed, consolidation across borders may be deterred by political factors, differences in institutions and cultures, the use of different payment and settlement systems, and differences in capital markets, taxes, and regulations across the nations (e.g., Giddy, Saunders, and Walter 1996, Lannoo and Gros 1998, Boot 1999, Blandon 2000, Goddard, Molyneux, and Wilson 2001).

Recent research has also examined the expansion of bank reach through methods other than consolidation. One dimension examines purchases of equity stakes in foreign banks (e.g., Focarelli and Pozzolo 2001a,b). These studies found that banks take equity positions in foreign banks in nations where expected economic growth rates are high, the banking system is inefficient, banking markets are unconcentrated, and regulations are lax. Banks that take equity stakes in foreign banks tend to be relatively large, profitable, and from nations with more developed banking markets. Another dimension of bank reach is cross-border lending, in which banks lend across borders without necessarily establishing a significant physical presence in the foreign nations. ${ }^{1}$ These studies show that cross-border financial asset flows are driven by the same factors as international M\&As, and that the distance at which banks lend internationally has not increased over time with deregulation, technological advances, and expansions in cross-border nonfinancial activity (Buch 2001, forthcoming). ${ }^{2}$

Overall, the literature on bank nationality is not very definitive as to the advantages and disadvantages of host nation banks, home nation banks, and third nation banks, and the evidence on bank reach suggests that banks have expanded less than might be expected based on the declines in explicit barriers to competition. Importantly, the prior literature does not provide specific evidence on the nationality and reach of banks that provide cash management services to the foreign affiliates of large, multinational corporations, which is studied here. As described above, the provision of these services to these firms lies in the crucial middle ground of financial services that could be provided either by local host nation banks, global banks headquartered in a few financial

\footnotetext{
${ }^{1}$ Cross-border bank lending can be quite large. For example, international syndicated bank lending to firms in developed countries averaged $11 \%$ of total GDP in the 1990s, roughly equivalent to the level of corporate bond issuances, and over five times the amount of equity issued during the same period (Davies and Smith 2001).

${ }^{2}$ This latter result contrasts with research showing that the average distance from U.S. banks to small business loan customers within the U.S. has been increasing over time (Cyrnak and Hannan 2000, Petersen and Rajan 2002).
} 
centers, but with offices in many nations, or by institutions between these extremes.

\section{Data description}

Our source of information for connecting foreign affiliates of multinational corporations with their banks is GlobalCash-Europe96, a survey of cash management and electronic banking practices conducted in 1996 across 20 European nations by The Bank Relationship Consultancy and the School of Management at the University of Bath. The survey consists of a twelve-page questionnaire containing 60 questions, made available in ten different languages. The questionnaire was mailed to cash managers in 5,800 companies and completed by 1,129, for a response rate of $19.5 \%$. For verification purposes, all responses were followed up with phone interviews. ${ }^{3}$

The term cash management, as it is applied here, may be a misnomer. The services covered in the survey relate to all short-term banking services including lending, deposit-taking, liquidity management, foreign exchange management, and other financial services. According to survey respondents, one of the most important cash management services provided by banks is short-term financing. For example, in response to the question, "What operations come under the heading of cash management in the company in which you are working?," $90.2 \%$ of the sample firms listed at least one of three "lending-related" activities - short-term lending, trade finance, and creditor management - as part of their cash management operations. These choices as a group are second only to the group "liquidity-related" activities. Because short-term credit is the predominant form of bank financing in Europe (Rajan and Zingales 1995), it is likely that cash management banks are often the firms' primary lending banks. Importantly, many of the cash management services require a physical presence of the bank. As a result, these services can only be performed by a host nation bank or a physical office of a home nation or third nation bank. Thus, the lending across borders without establishing a significant physical presence in the foreign nations discussed above does not apply to these banks chosen for cash management services.

The survey asks corporations to identify the banks used by their foreign affiliates for cash management within each of the 20 nations. For expositional ease, we refer to these foreign affiliates as the "firms" in our sample. Our sample starts with the operations of 2,118 firms associated with the 1,129 respondents, or about two affiliates per responding corporation on average. Although we only track the operations of these corporations within the 20 survey nations, their headquarters may be anywhere. Most of these corporations are headquartered in other European nations, although many are headquartered in the U.S., Japan, and Canada.

\footnotetext{
${ }^{3}$ See Ongena and Smith (2000) for a detailed description of the survey.
} 
A respondent can identify up to two banks - a "primary" and "secondary" bank - that it uses for cash management services in a given country. Correctly classifying the nationality and reach of the sample banks requires that we link banks that share a common parent corporation or holding company. To do this, we first collect ownership information from the Fitch IBCA database on all banks listed by survey respondents. Next, we identify all ownership positions in which one bank (the "parent") owns at least $51 \%$ of equity of another bank (the "subsidiary") and assume that such subsidiaries are effectively controlled by the parent bank. In other words, subsidiaries that are majority-owned by their parent bank take on the nationality and reach of the parent. Under these criteria, 255 different banks provide cash management services for the 2,118 sample firms. To avoid biases associated with double counting, we report all sample statistics using only the firm's primary bank choice (although we explore robustness using an alternative definition that may include the secondary bank).

For each firm-bank observation, we identify bank nationality based on the location of the headquarters of a bank relative to the firm it serves. A host nation bank is headquartered in the country in which the firm operates, a home nation bank is headquartered in the same country as the firm's multinational corporate headquarters, and a third nation bank is headquartered outside of the home and host countries.

We define a bank's reach in terms of its geographic scope and size. Banks with the widest reach, global banks, provide services to sample firms in at least nine of the 20 European nations and have at least $\$ 100$ billion in consolidated assets as of year-end 1995 (assets taken from the American Banker). These criteria imply that eight of the 255 sample banks are global. Local banks are defined to have limited reach. These banks only provide services to sample firms in the European nation of their headquarters and have assets of less than $\$ 100$ billion. By definition, all local banks serve only as host nation banks and never as home nation banks or third nation banks, which require a cross-border presence. There are 174 local banks in our sample. A regional bank lies between these extremes, operating in more nations or being larger than a local bank, and operating in too few nations or being too small to be a global bank. Regional banks are either mid-sized European institutions or nonEuropean banks that have fairly limited European reach. There are 73 regional banks in our sample.

We acknowledge that our definitions of global, regional, and local banks are somewhat arbitrary and Eurocentric. We may classify some banks as global that may not be truly global, but have broad European presence. However, our definitions should be fairly representative for two reasons. First, the eight banks are generally recognizable as true global banks in terms of size and world coverage. As shown in Table 1, five of the 
global banks are based in Europe and the other three are from the U.S. Seven are ranked among American Banker's 50 largest banks in the world in 1995, and five operate in at least 18 of the 20 nations in our sample. Second, our findings are materially unchanged when we alter the dividing lines between global and regional banks, and between regional and local banks by adjusting the number of nations or asset size requirements.

The top row of Table 2 shows the distribution of choices of bank nationality and reach across all 2,118 firms. With respect to bank nationality, a surprising finding is that nearly two-thirds of all firms (65.5\%) choose a bank headquartered in the host nation, while the remaining firms split evenly between using a home nation bank $(17.7 \%)$ or third nation bank (16.9\%). This pattern suggests that the concierge effect is strong and tends to dominate the home cookin' effect. This finding also goes against the common perception from the "follow your customer" literature that firms will favor their home nation bank for all their banking services when operating in foreign countries. With respect to bank reach, firms choose global banks $35.1 \%$ of the time, regional banks $52.8 \%$ of the time, and local banks $12.0 \%$ of the time. These data suggest that while the vast majority of the foreign affiliates of multinational corporations prefer banks that span multiple nations (i.e., global or regional banks), only about one-third choose global banks.

The remainder of Table 2 shows the distribution of bank nationality and reach choices within each of the 20 host nations, sorted by the total size of the nation's banking sector, and grouped into one of three categories: large banking sector, small banking sector, or former socialist nation. ${ }^{4}$ We separate the banking systems of the former socialist nations because they tend to have legal and financial systems that are underdeveloped relative to the Western European nations. The data show that choices of bank nationality can differ greatly across host nations. For example, only $26.2 \%$ of the firms operating in the former socialist countries use a host bank and $42.6 \%$ of these firms select a bank from a third nation. Variation across countries is especially apparent among the small banking sector countries. For instance, only $15.0 \%$ of the firms operating in Luxembourg use a host bank, compared with $85.3 \%$ in Sweden. The data on bank reach also show considerable variation across host nations. Interestingly, global banks are more frequently chosen for large banking sector nations $(42.5 \%)$ and for former socialist nations (45.4\%) than for small banking sector nations $(21.9 \%)$. This observed pattern seems to indicate that global banks prosper best in markets open to bank competition (large banking sector nations) and in markets

\footnotetext{
${ }^{4}$ The size of a nation's banking sector is measured by its 1995 total domestic bank assets and is taken from the data set accompanying Barth, Caprio, and Levine (2001).
} 
that lack an established banking system (former socialist nations). We explore this possibility later in the paper. There is also notable variation in reach among the large banking sector nations. For example, more than twothirds of sample firms operating in France use a global bank, most of the firms operating in Switzerland and the UK use regional banks, while more than two-thirds of the firms operating in Italy use local banks. In our econometric model, we test for the effects of the variation across European nations in banking sector size, financial development, legal structure, and other factors on the extent of bank globalization.

Table 3 reports the distribution of bank nationality and reach sorted by the home nation of the firm, including home nations other than the 20 European nations. Foreign affiliates with corporate headquarters in both large and small banking sector European nations select a host nation bank $70 \%$ of the time and opt for their home nation only about $11 \%$ of the time. This result holds despite the close proximity of European nations. Of course, these averages mask significant variation across nations. The four foreign affiliates headquartered in the former socialist nations all choose host nation banks, perhaps reflecting a lack of domestic bank development within the nations, although this is a very small sample. In contrast, firms that are headquartered in the U.S. choose home nation banks more than $40 \%$ of the time, much more often more than firms from other nations. This finding may reflect the relatively high efficiency of U.S.-owned banks when operating in other nations already discussed, greater desires for control of foreign affiliates by U.S. corporations or their home nation banks, or other explanations. Finally, it is notable that many firms from other developed nations rarely choose home nation banks. Firms headquartered in Canada, Japan, and a few of the small-banking-sector European nations never select home nation banks, although these samples are small. However, the large number of firms headquartered in Germany, the UK, and Switzerland, which have large banks at home, also very seldom choose home nation banks. ${ }^{5}$

\section{Methodology}

Given the stylized facts, we next set up our empirical model of firm choice of bank nationality and reach. We first motivate the model with a two-stage decision tree, and then introduce the nested multinomial logit procedure and define the explanatory variables employed in the regressions.

\footnotetext{
${ }^{5}$ A possible explanation for some of the variation in the data is that corporations that tend to have exclusive banking relationships in their home nation may also be more likely to choose a home nation bank for affiliates operating abroad. However, Table 3 does not appear to support this argument. Corporations in Norway and Sweden typically maintain one domestic bank relationship (Ongena and Smith 2001), but choose to use host nation banks outside of their country more often than firms in Italy and Portugal, where it is common for firms to maintain many domestic banking relationships.
} 


\subsection{Two-stage decision tree}

In the model, we maintain that bank nationality is of primary importance in the choice of bank by foreign affiliates of large, multinational corporations, and that this choice of bank nationality may have an important influence on bank reach. As shown in the two-stage decision tree in Figure 1, firms first decide on the nationality of their bank (the top "branches") and then conditional on that choice, choose bank reach (the bottom "branches"). By definition, a local bank arises as a choice only when a firm first chooses a host nation bank, as a local bank does not have a cross-border presence in our data set. Therefore, conditional on choosing a home nation or third nation bank, a firm can only select a bank that is either global or regional.

Although our discussion is couched almost entirely in terms of the decisions firms make in selecting banks, we recognize that the observed outcomes also reflect the willingness and ability of banks to supply these services. For example, a foreign affiliate of a multinational corporation operating in Hungary might prefer the services of a host nation bank with global reach, but find that no bank provides this combination of bank nationality and reach, perhaps because the size of the host nation banking market is too small, the legal structure is too undeveloped, or the barriers to cross-border banking are too high. To the extent possible, we will try to control for such supply factors in our empirical model below by including explanatory variables that reflect the banking environment in the host nation.

At the nodes of the top branches of the tree in Figure 1, we report the sample frequencies of choosing a host nation, home nation, and third nation bank, while at the bottom branch nodes, we report the sample frequencies of choosing a global, regional, and local bank, conditional on the choice of nationality. As documented above, most firms choose host nation banks over home and third nation banks, consistent with a strong concierge effect. The new information in Figure 1 consists of the conditional reach frequencies. Firms' preferences for bank reach differ greatly depending on the choice of bank nationality. Conditional on choosing a host bank, firms select a global bank only $20.5 \%$ of the time. By comparison, when firms first choose a home bank, they have a $66.8 \%$ chance of selecting a global bank, and when they choose a third bank, they select a global bank $63.6 \%$ of the time. In other words, firms rely heavily on banks with a global reach whenever they choose a home or third nation bank, but prefer a regional or local bank when choosing a host nation bank.

One artifact of the data that could be driving the conditional reach probability patterns in Figure 1 is that only three host nations - France, Germany, and The Netherlands - have a global bank headquartered within their 
borders. That is, firms choosing a host nation bank in any of the other 17 nations in our sample cannot also select a global bank. This could simply reflect an equilibrium outcome, i.e., the demand for global services within these countries are not great enough to induce a host nation bank to expand its reach globally or to induce an existing global bank to move its headquarters to one of these countries. As discussed above, this outcome may reflect supply conditions in the host nation, and we try to control for these conditions in our logit regressions.

To gain some insight into how the distribution of bank choices might differ in a market where all types of banks are available, we focus in Figure 2 on Germany. Germany not only has a host nation bank that is global (Deutsche Bank), it also has a strong system of local and regional commercial banks from which firms may choose, including the nationwide systems of Landesbanken (state banks), Sparkassen (savings banks) and Hypothekbanken (building societies). Like Figure 1, Figure 2 shows that a substantial proportion of foreign affiliates of large multinational corporations operating in Germany choose a host nation (i.e., German) bank for their banking services. More important, conditional on selecting a German bank, firms still prefer a regional or local bank over a global bank by a two-to-one margin, while conditional on selecting a home or third nation bank, most firms prefer the services of a global bank.

The raw-data findings from Figures 1 and 2 provide strong support for the maintained assumptions of our model. The finding that most firms choose host nation banks - even when this precludes the selection of a global bank - supports our maintained assumption that bank nationality is of primary importance and is the choice made first in the decision tree. In addition, the finding that bank reach does vary substantially with the choice of host, home, and third nation supports the assumption that the choice of bank nationality may have a significant influence on the degree of bank reach, and may therefore be modeled as conditional on bank nationality.

\subsection{Econometric model}

Based on the tree structure of Figure 1, we construct a model of the choice of bank nationality and reach and show how that model can be estimated using the nested multinomial logit (NMNL) methodology proposed by McFadden (1978). In the first stage, we assume that firms pick bank nationality as a function of host nation characteristics, geographic, cultural, and financial differences between the home and host nations, and attributes of the multinational corporations. We hypothesize that firms base their nationality decision on the relative attractiveness of the concierge effect, which tends to push a firm towards a host nation bank, vis-à-vis the home cookin' effect, which tends to push a firm towards a home nation bank. Firms may choose third nation banks 
when the concierge and home cookin' effects are both relatively weak. As discussed further below, some of the explanatory variables are included in part to control for factors that affect the willingness and ability of banks to supply services in the relevant nations.

Let $Y_{i}^{\mathrm{N}}$ be a discrete-valued dependent variable that takes on the value of 0,1 , or 2 depending on whether firm $i$ chooses a host, home, or third nation bank, respectively. We assume that the discrete value $Y_{i}^{\mathrm{N}}$ is the observed outcome from a continuously-valued, latent variable $Y_{i}^{\mathrm{N}^{*}}$ that reflects the net benefits flowing to a firm from selecting a host, home, or third nation bank. The first stage of our model is:

$Y_{i}^{\mathrm{N}^{*}}=f($ Host Nation Characteristics, Differences between Home and Host Nations, Corporate Attributes).

In the second stage, the firm chooses bank reach conditional on the nationality choice and attributes of the corporation. We hypothesize that firms base their bank reach decisions on the tradeoff between having access at the corporate level to the broad product ranges and expertise associated with banks with extensive reach versus the benefits from relationship-oriented services and country-specific knowledge associated with banks with relatively short reach. We assume the existence of a latent variable $Y_{i}^{\mathrm{R} \mid \mathrm{N}^{*}}$ that reflects the flow of benefits to firm $i$ from choosing a global, regional, or local bank (assigned the values of 0,1 , or 2 , respectively), conditional on the nationality chosen in the first stage,

$Y_{i}^{\mathrm{R} \mid \mathrm{N}^{*}}=h_{N}($ Corporate Attributes $), N=(0,1,2)$.

Note that when the nationality choice is a home $(\mathrm{N}=1)$ or third nation bank $(\mathrm{N}=2)$, then the choice $Y_{i}^{\mathrm{R} \mid \mathrm{N}^{*}}$ is limited to either a global or regional bank because local banks do not have a cross-border presence.

Following McFadden (1978), we assume that $Y_{i}^{\mathrm{N}^{*}}$ and $Y_{i}^{\mathrm{R} \mid \mathrm{N}^{*}}$ are linear in their regressors and that the regressions errors follow a generalized extreme-value distribution. This assumption implies that we can write the joint probability of observing a firm choosing nationality $N$ and reach $R$ as

$\operatorname{Pr}(N, R)=\frac{\exp \left(\alpha_{1}{ }^{\prime} Z_{N}^{\text {Host Nation }}+\alpha_{2}{ }^{\prime} Z_{N}^{\text {Differences between Home and Host Nation }}+\beta_{N}{ }^{\prime} Z_{N, R}^{\text {Corporate }}\right)}{\sum_{N=0}^{2} \sum_{R=0}^{2} \exp \left(\alpha_{1}{ }^{\prime} Z_{N}^{\text {Host Nation }}+\alpha_{2}{ }^{\prime} Z_{N}^{\text {Differences between Home and Host Nation }}+\beta_{N}{ }^{\prime} Z_{N, R}^{\text {Corporate }}\right)}$,

the conditional probability of choosing $\mathrm{R}$ given $\mathrm{N}$ as 


$$
\operatorname{Pr}(R \mid N)=\frac{\exp \left(\beta_{N}^{\prime} Z_{N, R}^{\text {Corporate }}\right)}{\sum_{R=0}^{2} \exp \left(\beta_{N}^{\prime} Z_{N, R}^{\text {Corporate }}\right)}
$$

and the unconditional probability of choosing $\mathrm{N}$ as

$$
\operatorname{Pr}(N)=\frac{\left.\exp \left(\alpha_{1}{ }^{\prime} Z_{N}^{\text {Host Nation }}+\alpha_{2}{ }^{\prime} Z_{N}^{\text {Differences between Home and Host Nation }}\right) \sum_{\mathrm{R}=0}^{2} \beta_{N}{ }^{\prime} Z_{N, R}^{\text {Corporate }}\right)}{\sum_{N=0}^{2} \exp \left(\alpha_{1}{ }^{\prime} Z_{N}^{\text {Host Nation }}+\alpha_{2}{ }^{\prime} Z_{N}^{\text {Differences between Home and Host Nation }}\right) \sum_{R=0}^{2} \exp \left(\beta_{N}{ }^{\prime} Z_{N, R}^{\text {Corporate }}\right)} .
$$

Define what McFadden (1978) terms to be the "inclusive value"

$$
I_{N}=\ln \left(\sum_{\mathrm{R}=0}^{2} \beta_{N}{ }^{\prime} Z_{N, R}^{\text {Corporate }}\right)
$$

then equation (6) can be expressed as:

$$
\operatorname{Pr}(N)=\frac{\exp \left(\alpha_{1}{ }^{\prime} Z_{N}^{\text {Host Nation }}+\alpha_{2}{ }^{\prime} Z_{N}^{\text {Differenceses between Home and Host Nation }}+\rho I_{N}\right)}{\sum_{N=0}^{2} \exp \left(\alpha_{1}{ }^{\prime} Z_{N}^{\text {Host Nation }}+\alpha_{2}{ }^{\prime} Z_{N}^{\text {Differences between Home and Host Nation }}+\rho I_{N}\right)} .
$$

Again, when $\mathrm{N}=1$ or 2 (home or third nation bank), then R can be only 0 or 1 (global or regional bank).

The parameters $\alpha, \beta_{\mathrm{N}}$, and $\rho$ are estimated by working backwards on the Figure 1 decision tree, applying multinomial logit at each stage. First, the $\beta_{\mathrm{N}}$ are estimated at each nationality node $(\mathrm{N}=$ home, host, and third) by regressing the conditional bank reach observations $Y_{i}^{\mathrm{R} \mid \mathrm{N}}$ on corporate characteristics. Then, estimated values of $\beta_{\mathrm{N}}$

are used to construct inclusive values for each nationality node using equation (4). These inclusive values summarize the impact of corporate characteristics on the reach decision, conditional on a given choice of nationality. In the second step, $\alpha$ and $\rho$ are estimated by regressing the bank nationality observations $Y_{i}^{\mathrm{N}}$ on host nation characteristics, differences between home and host nation characteristics, and the inclusive values.

\subsection{Explanatory variables}

The explanatory variables include characteristics of the host nation, geographic, cultural, and financial differences between the home and host nations, and attributes of the multinational corporation of which the foreign affiliate is a part. Table 4 lists these variables and their summary statistics. The continuous variables, such as dollar amounts and distance, are included in the regressions as the natural logs of the variables (denoted by $\ln$ ), although we show the summary statistics for both the levels and logs.

As discussed above, firms choose bank nationality in our model based primarily on whether the concierge 
benefits of a host nation bank versus the home cookin' benefits of a home nation bank dominate. Firms may select a third nation bank if neither set of benefits is very important. We also control for some supply-related factors.

The host nation characteristics proxy for both the demand for concierge benefits from host nation banks and the willingness and ability of banks to supply these services within a host nation. There may be more need for concierge services in host nations with less well developed financial and legal systems, but it may also be more difficult for host nation banks to supply these services when the infrastructure of the nation is less developed. As one proxy for both financial and legal development, we include the dummy variable Former Socialist Nation that equals one when the host nation is the Czech Republic, Hungary, or Poland. Recent transitions to market economies imply that the financial systems of former socialist countries are likely to be significantly underdeveloped relative to other European countries. We also include two continuous measures of financial development, Bank Assets/GDP and Market Capitalization/GDP. Bank Assets/GDP measures the importance of the host nation's banking sector in terms of the nation's aggregate domestic bank assets relative to GDP. Similarly, Market Capitalization/GDP measures the importance of the host nation's capital markets by summing the value of private sector debt and market capitalization of stock market equity and dividing the sum by GDP. Exports/GDP is value of the nation's total exports divided by GDP. It measures the degree of reliance firms within a nation have on cross-border product markets and is a measure of potential demand for cross-border banking services. Bank Assets/GDP, Market Capitalization/GDP, and Exports/GDP are all measured at year-end 1995 and are taken from Barth, Caprio, and Levine (2000). As a legal development variable, we specify Creditor Protection, a dummy that takes the value one when a country has both strong creditor protection laws and a good tradition of legal enforcement. This variable is calculated using the creditor rights and legal enforcement indexes created by LaPorta, Lopez-de-Silanes, Shleifer, and Vishny (1997). ${ }^{6}$

The geographic, cultural, and financial differences between the home and host nations also proxy for some demand and supply effects. Demand for concierge services should be greater when the home and host

\footnotetext{
${ }^{6}$ The creditor rights index summarizes a country's laws regarding creditor restrictions on other stakeholders (such as minimum dividends or consent to file for reorganization), automatic stays, guarantees of priority, and who obtains control during bankruptcy. The index ranges between zero and four with a four corresponding to the strongest laws favoring creditor rights. The enforcement index measures the law and order tradition in a country. It runs on a scale between zero and ten, with higher values corresponding to a stronger enforcement tradition. Creditor Protection equals one if the creditor rights index is higher than two and the enforcement index is higher than six.
} 
nations are very different. Moreover, the ability for a home nation bank to supply home cookin' benefits may become more difficult, the more different is the home nation from the host nation. Both effects predict that when the differences between home and host characteristics are greater, a host nation bank is more likely to be chosen and a home nation bank is less likely to be chosen. We construct a variety of variables so that a higher number indicates a greater difference between the home and host nation, taking absolute values of differences where necessary. The variable $\ln$ (Distance) measures the natural log of the distance in miles between the host and home nation's financial capitals. Language Difference equals one when the host and home nations do not share any common official languages, and takes the value zero if any of the official languages of the home nation match any of the official languages of the host nation. The variables $\Delta \ln ($ Bank Assets/GDP), defined as the absolute value of the $\log$ difference $\mid \ln \left(\right.$ Bank Assets $\left./ G D P_{\text {Home }}\right)$ - $\ln \left(\right.$ Bank Assets $\left./ G D P_{\text {Host }}\right) \mid$, and $\Delta \ln ($ Market Capitalization/GDP), defined similarly to be $\mid \ln \left(\right.$ Market Capitalization $\left./ G D P_{\text {Home }}\right)-\ln \left(\right.$ Market Capitalization/GDP $\left.P_{\text {Host }}\right) \mid$, measure the magnitude of the differences in financial development between the home and host nations.

Finally, attributes of the multinational corporation of which the foreign affiliate is a part could influence the choices of bank nationality and bank reach and are included in both sets of equations. Relatively large corporations with product reach that extends across many nations could have developed enough in-house expertise so that neither concierge nor home cookin' benefits have much value. Such corporations may rely more on third nation banks than corporations where one of the two effects is important. Large companies and companies with extended product reach may also prefer global banks because of the range of products they offer, while small companies and companies that value relationship-based financing should prefer banks that emphasize their local reach. Ln Sales, the log of the corporation's 1995 consolidated sales, acts as a proxy for the size of the corporation. ${ }^{7}$ Number of Nations Doing Business is the number of European nations in which the corporation reports doing business. Relationship Importance is an assessment made by the survey respondent as to the perceived importance of their relationship with a given bank, among a set of nine other specified criteria, in allocating business between existing banks. We assign a one to the variable if company managers answered that a relationship was "important" or "very important," and a zero otherwise. We posit that foreign affiliates of

\footnotetext{
${ }^{7}$ Corporations do not actually report exact sales figures. Instead, they categorize their total sales into one of eight intervals, beginning with "less than $\$ 100$ million" and ending with "greater than $\$ 10$ billion". To obtain a value for sales that is economically meaningful, we convert each categorical response to the midpoint dollar value in that category. A corporation that selects the category "less than $\$ 100$ million" gets coded as having sales of $\$ 50$ million. For companies reporting sales "greater than $\$ 10$ billion," we select the value $\$ 20$ billion.
} 
companies that rank relationship importance high will be more likely to choose a local or regional bank that can offer stronger relationship services than a global bank. Finally, we include dummy variables to control for industry-specific effects. Specifically, we group companies into one of four broad industry categories: Farming and Mining, Manufacturing, Services and Trade, or other industry, with the other industry category excluded from the specification as the base case.

\section{Results}

Tables 5-7 contain the results of the two-stage NMNL model. For each of the tables, we compute and report estimated partial derivatives that measure the impact of small changes in each of the explanatory variables on the probability of observing a given bank choice, holding the other variables constant, evaluated at the sample mean of the explanatory variables. We write this as $\partial \operatorname{Pr}(N) / \partial Z_{\bar{z}}$ when evaluating bank nationality and $\partial \operatorname{Pr}(R) / \partial Z_{\bar{z}}$ when evaluating bank reach. The sums of the estimated derivatives equal zero across a given set of choices of bank nationality (host nation, home nation, or third nation) or bank reach (global, regional, or local) because the sums of the probabilities must equal one.

We also report all results using two different definitions of bank nationality and reach. The first definition - used in the summary statistics and shown in the earlier figures and tables - is based on the firm's primary bank and ignores the firm's secondary bank. The second definition maximizes the measured reach of the bank by replacing the primary bank with the secondary bank in cases in which the secondary bank has greater reach. That is, for the second definition, the secondary bank's nationality is used if the primary bank is a local bank and the secondary bank is regional or global, or if the primary bank is regional and the secondary bank is global. Because the results are similar across the two definitions, we focus on the findings using the first definition.

\subsection{Bank Nationality Regressions}

Table 5 contains the estimated partial derivatives from the regression of bank nationality choice on host nation characteristics, geographic, cultural, and financial differences between the home and host nations. The table also reports the impact of the corporate attributes on nationality, imputed from the inclusive value estimates obtained from the reach regressions shown below. Several interesting patterns emerge from the table.

First, holding the other variables constant, firms operating in socialist nations are less likely, by 37.3 percentage points, to choose a host nation, all else equal, and are instead more likely to choose a home nation bank (by 24.4 percentage points) or third nation bank (by 12.9 percentage points). This effect of being in a former 
socialist nation explains most, but not nearly all of the observed difference in means shown in Table 2 above, in which the frequencies for former socialist nations choosing host nation banks (26.2\%) were on average more than 40 percentage points below the large banking sector nations (69.1\%) and small banking sector nations $(67.0 \%)$. This finding is consistent with the hypothesis that financial systems within former socialist countries may be too new and underdeveloped in some cases to create banks with sufficient concierge services, so that many foreign affiliates of multinational corporations may rely instead on banks from other nations. Most of the other host nation characteristics do not have a statistically significant effect on the choice of bank nationality, except that greater exports are associated with a greater probability of choosing a third nation bank and a lesser probability of choosing a home nation bank.

Second, the estimates on the variables that measure differences between the home and host nations generally do not support the hypothesis that relatively large geographic, cultural, and financial differences between the two nations make it more likely that a firm will use a host nation bank for cash management services. In fact, the relation between all of these variables and the likelihood of choosing a host nation bank are negative or zero. For instance, firms become significantly less likely to use a host nation bank and more likely to use a home nation bank or third nation bank as the geographical distance between the home and host increases. The partial derivative estimates imply that a $10 \%$ increase in distance from the mean of $\ln$ (Distance) is predicted to increase the likelihood of choosing a home nation bank by about 0.49 percentage points $(0.052 * \ln (1.10))$ and a third nation bank by roughly 0.12 percentage points $(0.013 * \ln (1.10))$. Firms are significantly more likely to choose a third nation bank when the home and host do not share a common language and when the difference in size of the two nations' banking sectors is large. The Language Difference estimate implies that lack of a common language between the home and host nations leads to 7.1 percentage point increase in the likelihood of choosing a third nation bank. The estimate on $\Delta \ln$ (Bank Assets) suggests that an increase of $10 \%$ in the mean value of the absolute difference between the logged size of the two nations' banking sectors implies a 0.36 percentage point increase in the likelihood of selecting a third nation bank.

The results on the variables that measure differences between the home and host nations could be driven in part by U.S. multinational corporations, which come from a home nation that is located relatively far from the host nations and has relatively large capital markets, yet has firms that rely heavily on home nation banks (see Table 3). As discussed earlier, this may reflect in part the relatively high efficiency of U.S. banks in other nations, 
or preferences for control by the U.S. corporations or home nation banks. To test the extent to which the behavior of these firms may explain the anomalous results for the differences between home and host nations, we try removing the foreign affiliates of U.S. corporations from the sample (not shown in tables). The estimate on In(Distance) switches signs to become positive and significant and the estimate on Language Difference becomes positive but not significant, while all other estimates remain the same sign and of similar magnitude. Thus, without the U.S. firms, the signs on $\ln$ (Distance) and Language Difference are consistent with our hypothesis that coming from a more distant home nation or one that does not share a language with the host nation improves the value of concierge benefits and makes firms more likely to rely on a host nation bank.

The imputed corporate attribute estimates suggest that as corporations become larger and operate in more European nations, they become significantly less likely to use a host nation bank and more likely to use a home nation bank. This result could reflect that larger and more far-flung corporations have less demand for concierge services in each individual foreign nation. Alternatively, it may suggest that some banking organizations engage in "follow-your-customer" strategies that target their home customers as they grow and expand.

\subsection{Conditional Bank Reach Regressions}

Table 6 reports the results from the regressions of bank reach on corporate attributes, conditioned first on the nationality of the bank. Three sets of estimates are given, depending on the bank nationality chosen in the first stage of the decision tree. Conditional on choosing a host nation bank, firm may choose a bank with global, regional, or local reach. Conditional on choosing a home nation or third nation bank, firms can only choose between a global and regional bank. Comparing the estimates for the different nationality choices gives a sense for how nationality choice influences the reach decision.

Conditional on choosing a host nation bank, firms appear to become more likely to select a regional bank rather than a local bank as they become larger in terms of $\ln ($ Sales). Interestingly, size does not appear to influence the likelihood of selecting a global bank. However, firms become less likely to choose a global bank as the number of countries in which their corporation does business increases. In contrast, firms that have chosen a home nation bank appear to be more likely to select a global bank as they become bigger and as the number of countries in which they do business increases. Finally, conditional on choosing a third nation bank, little variation in the reach choice is explained by our variables.

At first blush, the effect of $\ln$ (Number of Nations Doing Business) on choice of bank reach for firms that 
choose host nation banks may seem counterintuitive. It might be expected that firms that use host nation banks would rely more on global banks as they do business in more nations, as we find that firms do when they use home nation banks. However, this result is consistent with the hypothesis that as these corporations expand internationally, they may prefer the mix of services from regional banks that have better expertise about the foreign nations in which they operate, and still provide a reasonably wide variety of international services.

Table 7 shows imputed partial derivative estimates of the unconditional impact of the explanatory variables on bank reach. The unconditional probability of choosing a bank of a given reach, $P(R)$, can be expressed as:

$P(R)=\sum_{N=0}^{2} P(R \mid N) \cdot P(N)$

Partial derivatives can then be computed using the chain rule:

$\frac{\partial P(R)}{\partial Z}=\sum_{N=0}^{2}\left[\frac{\partial P(R \mid N)}{\partial Z} \cdot P(N)+P(R \mid N) \cdot \frac{\partial P(N)}{\partial Z}\right]$

We obtain estimates in Table 7 by replacing the right hand side of equation (9) with the estimates of $\frac{\partial P(N)}{\partial Z}$ and $\frac{\partial P(R \mid N)}{\partial Z}$ from Tables 5 and 6, respectively, and fitted values of $P(N)$ and $P(R \mid N)$. Standard errors for the imputed estimates are calculated in a similar fashion. Note that equation (9) reflects the effects of all three sets of explanatory variables on bank reach through their effects on the choice of bank nationality, as well as the direct effects of the corporate attributes.

Most of the signs of the derivatives on host nation characteristics shown in Table 7 are consistent with expectations, although there is not much statistical significance. The findings suggest that firms operating in former socialist nations are more likely to choose a global bank and less likely to choose a local bank, consistent with expectations that these firms more often need the wide range of services and expertise of a global bank, rather than a local bank headquartered in a former socialist nation. Firms also become more likely to use a global bank as the distance between the host and home nations increases, although this may be driven in part by the presence of U.S. firms. Finally, the data also suggest that larger firms are more likely to choose greater bank reach, consistent with expectations. 


\section{Conclusion}

In this paper, we examine bank globalization along two dimensions - bank nationality and bank reach using data on cash management services provided to foreign affiliates of large multinational corporations. These firms represent a significant portion of the potential market for global banks and should therefore be influential in determining the extent to which the banking industry will become globalized. The provision of cash management services to such firms represents a crucial "middle ground" of financial services that could be provided by a range of different institutions - from a small bank headquartered in the host nation to a large global bank headquartered in a distant financial center.

We investigate bank nationality and reach using a two-stage nested multinomial logit model in which bank nationality is chosen first and may influence bank reach. Explanatory variables in the model include 1) host nation characteristics, 2) geographic, cultural, and financial differences between the home and host nations, and 3) attributes of the multinational corporations. The first two sets of variables are designed to reflect both the demand of the foreign affiliates of the multinational corporations for cash management services from banks of different nationalities and the willingness and ability of these banks to supply the services. The attributes of the corporations are assumed to affect both bank nationality and reach through the demand side alone.

We find that nearly two-thirds of our sample firms choose a bank headquartered in the host nation and less than $20 \%$ select a bank from their home nation. This is consistent with a strong "concierge" effect that dominates a "home cookin'" effect. That is, affiliates of multinational corporations often use banks that know the local market, culture, language, and regulatory conditions rather than banks that are more familiar with the conditions in the corporation's home market, or that have direct ties to the corporation in the home nation.

The data also suggest that bank reach is strongly associated with bank nationality. Firms that use host nation banks for cash management services are less likely to use a global bank and more likely to use a local or regional bank. Moreover, corporations that use host nation banks also tend to use regional banks as they expand internationally, whereas those that use home nation banks tend to rely on global banks as they expand. These findings together suggest that local and regional banks may be better at delivering concierge services than global banks, and large, multinational corporations need more concierge services as they expand further from their home nation. Overall, the finding that multinational corporations rely on host nation banks with limited reach suggests the extent of globalization may remain limited.

Our bank nationality and bank reach regressions yield some additional interesting results about the likely 
determinants of bank globalization. For example, we find that the very low levels of financial development in the former socialist nations appear to have strong effects on both bank nationality and bank reach. Firms operating in the former socialist nations of Eastern Europe are more likely to use home nation or third nation banks rather than host nation banks, and are also more likely to choose banks with a global reach rather than local reach.

We caution that the inferences we draw are subject to several caveats. First, we acknowledge that the financial structure of the banking industry reflects some supply and demand factors that are not modeled here. For instance, implicit barriers to competition might limit the supply of cash management services in some nations and therefore reduce the choice set available to our sample firms. Second, because our sample is simply a "snapshot" of the European market in 1996, our data do not necessarily reflect the long-run, steady-state equilibrium. For instance, the introduction of the Euro in 1999 - and its subsequent adoption as a physical currency in 2002 - may have reduced the costs of offering financial services across the borders of European Monetary Union (EMU) nations, making it easier for home and third nation banks to compete with host nation banks. ${ }^{8}$ Third, our measurement of bank reach is somewhat arbitrary and Eurocentric - we may classify some banks as global that only have substantial reach within Europe.

\footnotetext{
${ }^{8}$ However, a recent study that used an extensive panel of micro-level price data across Europe found that most of the benefits of European integration in terms of convergence in goods prices occurred in the early 1990s. Prices have been found to continue to converge after the introduction of the Euro, but at a slower rate than in the early 1990s (Rogers 2001).
} 


\section{References}

Barth, J.R., G. Caprio, and R. Levine. 2001. "The Regulation and Supervision of Banks Around the World: A New Database," World Bank working paper.

Beitel, P., and D. Schiereck. 2001. "Value Creation at the Ongoing Consolidation of the European Banking Market," Institute for Mergers and Acquisitions working paper.

Berger, A.N., R. DeYoung, H. Genay, and G.F. Udell. 2000. "Globalization of Financial Institutions: Evidence from Cross-Border Banking Performance.” Brookings-Wharton Papers on Financial Services 3: 23-158.

Berger, A.N., Klapper, L.F., Udell, G.F. 2001. "The Ability of Banks to Lend to Informationally Opaque Small Businesses," Journal of Banking and Finance 25: 2127-2167.

Berger, A.N., R. Demsetz, and P. Strahan. 1999. "The Consolidation of the Financial Services Industry: Causes, Consequences, and Implications for the Future," Journal of Banking and Finance 23: 135-194.

Blandon, J.G. 2000. “Cross-Border Banking in Europe: An Empirical Investigation,” Universitat Pompeu Fabra working paper.

Boot, A.W.A. 1999. "European Lessons on Consolidation in Banking," Journal of Banking and Finance 23: 609613.

Brealey, R.A., and Kaplanis, E.C. 1996. "The Determination of Foreign Banking Location," Journal of International Money and Finance 15: 577-597.

Buch, C.M. 2001. "Distance and International Banking," Kiel Institute of World Economics working paper No. 1043, Kiel, Germany.

Buch, C.M. forthcoming. "Information or Regulation: What is Driving the International Activities of Commercial Banks?" Journal of Money, Credit, and Banking.

Buch, C.M., and DeLong, G.L. 2001. “Cross-border Bank Mergers: What Lures the Rare Animal?” Kiel Institute of World Economics working paper No. 1070, Kiel, Germany.

Clarke, G., Cull, R., Martinez Peria, M.S. 2001. "Does Foreign Bank Penetration Reduce Access to Credit in Developing Countries? Evidence from Asking Borrowers," World Bank working paper.

Cyrnak, A., and T.H. Hannan. 2000. “Non-Local Lending to Small Businesses,” Federal Reserve Board working paper.

Davies, S., and D. C. Smith. 2001. "Trends in External Corporate Financing," Federal Reserve Board working paper.

DeLong, G. L. 2001. "Stockholder Gains from Focusing versus Diversifying Mergers," Journal of Financial Economics 59: 221-252.

DeYoung, R. and D.E. Nolle. 1996. "Foreign-Owned Banks in the U.S.: Earning Market Share or Buying It?" Journal of Money, Credit, and Banking 28(4): 622-636.

Focarelli, D., Pozzolo A.F. 2001a. "The Patterns of Cross-border Bank Mergers and Shareholdings in OECD 
Countries," Journal of Banking and Finance 25: 2305-2337.

Focarelli, D., Pozzolo A.F. 2001b. "Where Do Banks Expand Abroad? An Empirical Analysis,” Bank of Italy working paper.

Giddy, Ian, Anthony Saunders, and Ingo Walter. 1996. "Alternative Models for Clearance and Settlement: The Case of the Single European Capital Market," Journal of Money, Credit and Banking 28(4): 986-1000.

Goddard, J., Molyneux, P., and Wilson, J.O.S. 2001. European banking: Efficiency, Technology, and Growth. (Chichester, UK: John Wiley and Sons).

Goldberg, Lawrence G. and Anthony Saunders. 1981. "The Determinants of Foreign Banking Activity in the United States." Journal of Banking and Finance 5: 17-32.

Grosse, R., Goldberg, L.G. 1991. "Foreign Bank Activity in the United States: An Analysis by Country of Origin," Journal of Banking and Finance 15: 1093-1112.

Group of Ten, 2001, Report on Consolidation in the Financial Sector, http://www.bis.org/publ/gten05.htm.

Lannoo, Karel and Daniel Gros. 1998. "Capital Markets and EMU: Report of a CEPS Working Party,” Centre for European Policy Studies.

LaPorta, R., Lopez-de-Silanes, F., Shleifer, A., and Vishny, R.W. 1997. "Legal Determinants of External Finance," Journal of Finance 22: 1131-1150.

Levine, R. 1996. "Foreign Banks, Financial Development, and Economic Growth," in Claude E. Barfield, ed., International Financial Markets: Harmonization Versus Competition, Washington DC: The AEI Press.

McFadden, D. 1978. "Modelling the Choice of Residential Location," In A. Karlquist et al. (eds.), Spatial Interaction Theory and Residential Location, pp. 75-96. Amsterdam: North-Holland.

Ongena, S. and D.C. Smith. 2000. "What Determines the Number of Relationships? Cross Country Evidence," Journal of Financial Intermediation 9: 26-56.

Petersen, M.A. and R.G. Rajan. 2002. “The Information Revolution and Small Business Lending: Does Distance Still Matter?” Journal of Finance, forthcoming.

Rajan, R.G. and L. Zingales. 1995. "What Do We Know about Capital Structure? Some Evidence from International Data," Journal of Finance 50: 1421-1460.

Rogers, J.H. 2001. "Price Level Convergence, Relative Prices, and Inflation in Europe," Federal Reserve Board working paper, IFDP \#699.

Seth, R., Nolle, D.E. and Mohanty, S.K. 1998. “Do Banks Follow their Customers Abroad?," Financial Markets, Institutions, and Instruments 7: 1-25.

Stanley, T.O., Roger, C., McManis, B. 1993. "The Effects of Foreign Ownership of U.S. Banks on the Availability of Loanable Funds to Small Business," Journal of Small Business Management 31: 51-66.

Ter Wengel, J. 1995. "International Trade in Banking Services," Journal of International Money and Finance 14: 47-64. 


\section{Figure 1: Firm Choice of Bank Nationality and Reach - Firms Across All Host Nations}

This figure depicts the sample distribution of choices of bank nationality and bank reach in terms of a two-stage decision tree. The sample firms are foreign affiliates of large multinational companies operating in 20 European nations. The sample banks provide cash management services to these firms in these nations. A host nation bank is headquartered in the nation in which the affiliate operates, a home nation bank is headquartered in the same nation as the multinational corporation's headquarters, and a third nation bank is headquartered in neither the host nor the home nation. A global bank provides services to sample firms in at least nine of the 20 European nations and had at least $\$ 100$ billion in worldwide assets as of year-end 1995, a local bank provides services to sample firms only in the European nation of the bank's headquarters and had assets of less than $\$ 100$ billion, and a regional bank is neither global (too few nations or too small) nor local (too many nations or too large).

Bank

Nationality

\section{Bank}

Reach
Total sample of foreign affiliates across 20 European nations

(2,118 firms)

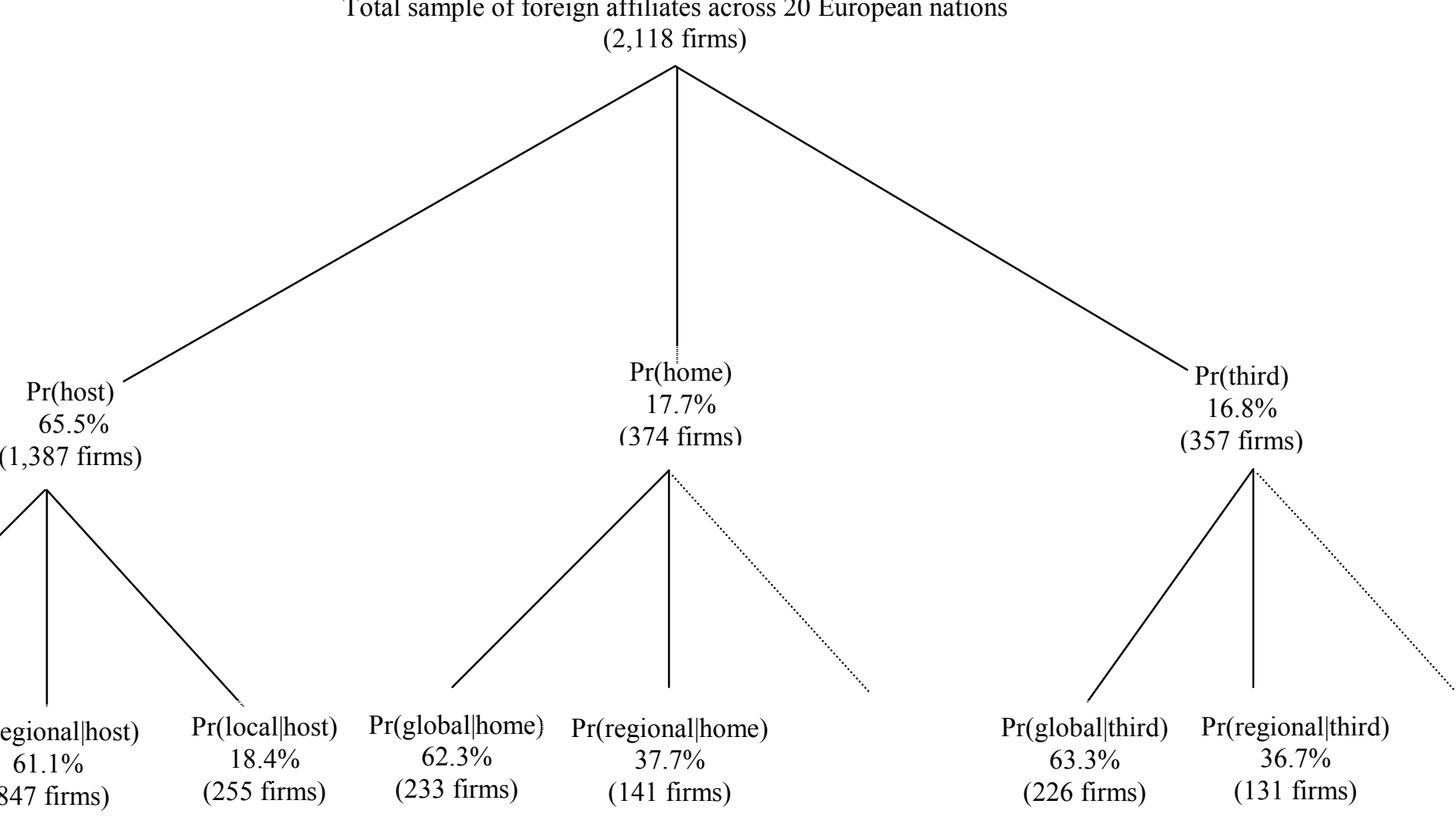




\section{Figure 2: Firm Choice of Bank Nationality and Reach -- Firms Operating in Germany}

This figure depicts the sample distribution of choices of bank nationality and bank reach in Germany in terms of a two-stage decision tree. The sample firms are foreign affiliates of large multinational companies operating in Germany, and the sample banks provide cash management services to these firms. A host nation bank is headquartered in the nation in which the affiliate operates, a home nation bank is headquartered in the same nation as the multinational corporation's headquarters, and a third nation bank is headquartered in neither the host nor the home nation. A global bank provides services to sample firms in at least nine of the 20 European nations and had at least $\$ 100$ billion in worldwide assets as of year-end 1995, a local bank in this figure is a German bank that provides services to sample firms only in Germany and had assets of less than $\$ 100$ billion, and a regional bank is neither global (too few nations or too small) nor local (too many nations or too large).

Bank

Nationality

Bank Reach
Total sample of foreign affiliates in Germany

(240 firms)

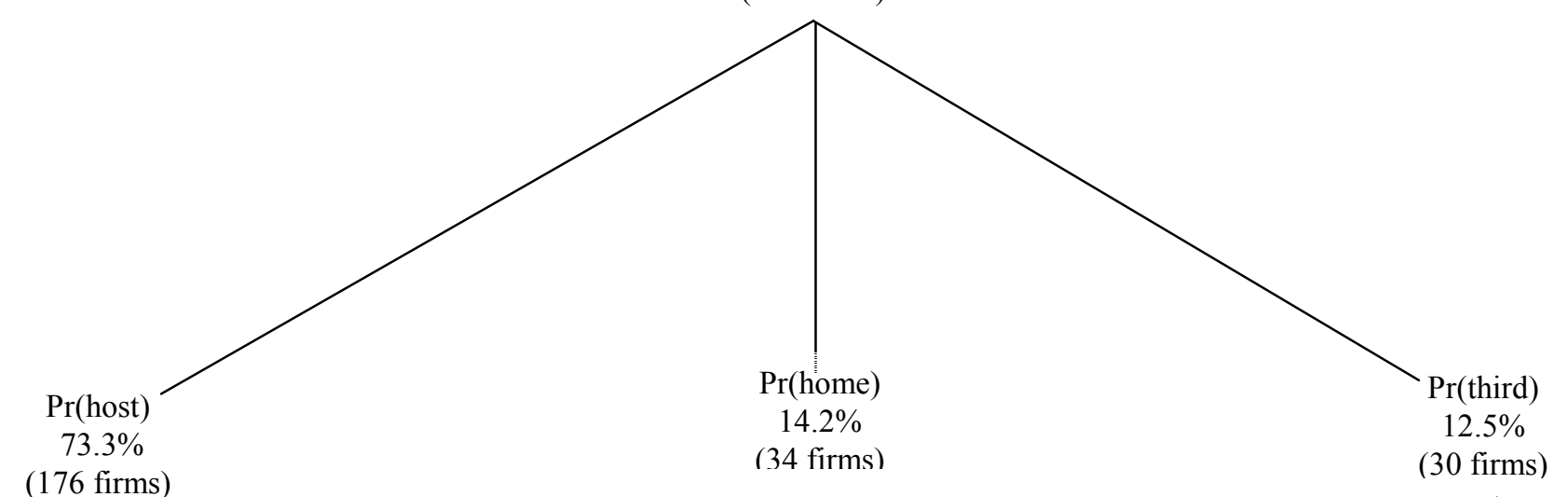

(176 firms)

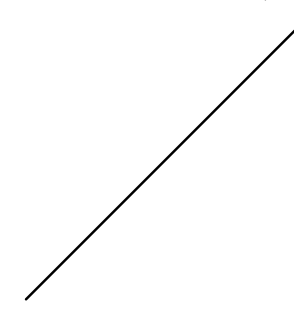

$\operatorname{Pr}$ (global|host) $\quad \operatorname{Pr}($ regional|host)

$34.1 \%$

$14.8 \%$

(60 firms)

(26 firms)

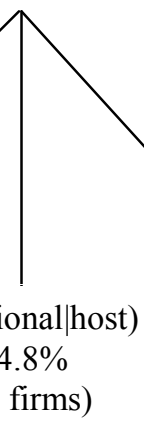

$\operatorname{Pr}$ (local|host)

$51.1 \%$

(90 firms)

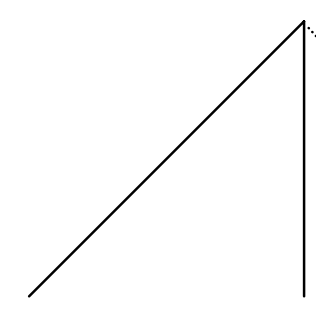

$\operatorname{Pr}($ global|home $) \quad \operatorname{Pr}($ regional $\mid$ home $)$

$55.9 \%$

(19 firms)
$44.1 \%$

(15 firms)

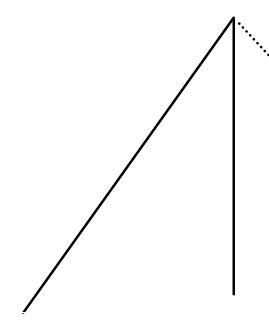

$\operatorname{Pr}($ global|third $) \quad \operatorname{Pr}($ regional|third $)$

$56.7 \% \quad 43.3 \%$

(17 firms) (13 firms) 


\section{Table 1: The Global Banks in the Sample}

This table lists the eight global banks in our sample, in order of descending size. These banks provide cash management services to sample firms in at least nine of the 20 European nations and had at least \$100 billion in worldwide assets as of year-end 1995.

\begin{tabular}{|c|c|c|c|c|}
\hline Bank Name & $\begin{array}{c}\text { Headquarters } \\
\text { Nation } \\
\end{array}$ & $\begin{array}{c}\text { Number of survey } \\
\text { nations in which the } \\
\text { bank operates }\end{array}$ & $\begin{array}{l}1995 \text { worldwide assets } \\
\text { (\$billions) }\end{array}$ & $\begin{array}{c}\text { American Banker } \\
\text { rank, by } 1995 \\
\text { worldwide assets }\end{array}$ \\
\hline Deutsche Bank & Germany & 10 & 502.3 & 1 \\
\hline ABN Amro & Netherlands & 19 & 339.4 & 12 \\
\hline Banque Nationale de Paris & France & 12 & 323.5 & 18 \\
\hline Citibank & US & 20 & 255.3 & 28 \\
\hline Bank of America & US & 18 & 230.2 & 34 \\
\hline Chase Manhattan Bank & US & 19 & 120.5 & 62 \\
\hline
\end{tabular}


Table 2: Distribution of Firm Choice of Bank Nationality and Reach, by Host Nation

This table reports the sample distribution of bank nationality and bank reach across the 20 European nations hosting the sample firms. Sample firms are foreign affiliates of large multinational companies, and sample banks are those identified by the firms as providing cash management services within each nation. A host nation bank is headquartered in the nation in which the affiliate operates, a home nation bank is headquartered in the same nation as the multinational corporation's headquarters, and a third nation bank is headquartered in neither the host nor the home nation. A global bank provides services to sample firms in at least nine of the 20 European nations and had at least $\$ 100$ billion in worldwide assets as of year-end 1995, a local bank provides services to sample firms only in the European nation of the bank's headquarters and had assets of less than $\$ 100$ billion, and a regional bank is neither global (too few nations or too small) nor local (too many nations or too large).

\begin{tabular}{|c|c|c|c|c|c|c|c|c|}
\hline \multirow[b]{2}{*}{ Nation } & \multirow[b]{2}{*}{$\begin{array}{l}\text { Number } \\
\text { of Firms }\end{array}$} & \multicolumn{4}{|c|}{ Bank Nationality (\%) } & \multicolumn{3}{|c|}{ Bank Reach (\%) } \\
\hline & & $\begin{array}{c}1995 \text { Total } \\
\text { Bank Assets }\end{array}$ & Host & Home & Third & Global & Regional & Local \\
\hline & & (billions \$) & & & & & & \\
\hline ALL FIRMS & 2,118 & & 65.5 & 17.7 & 16.9 & 35.1 & 52.8 & 12.0 \\
\hline \multicolumn{9}{|l|}{$\begin{array}{r}\text { Large banking- } \\
\text { sector nations }\end{array}$} \\
\hline Germany & 240 & 3,041 & 73.3 & 14.2 & 12.5 & 40.0 & 49.2 & 10.8 \\
\hline France & 223 & 1,527 & 76.7 & 12.1 & 11.2 & 66.8 & 17.0 & 16.1 \\
\hline UK & 224 & 1,278 & 52.2 & 29.0 & 18.8 & 25.9 & 71.9 & 2.2 \\
\hline Italy & 119 & 831 & 70.6 & 17.6 & 11.8 & 27.7 & 43.7 & 28.6 \\
\hline Switzerland & 103 & 557 & 76.7 & 15.5 & 7.8 & 13.6 & 78.6 & 7.8 \\
\hline Spain & 126 & 552 & 57.9 & 26.2 & 15.9 & 26.2 & 54.8 & 19.0 \\
\hline Netherlands & 166 & 457 & 78.3 & 11.4 & 10.2 & 76.5 & 21.1 & 2.4 \\
\hline Total & 1,201 & 8,241 & 69.1 & 17.9 & 13.0 & 42.5 & 46.1 & 11.4 \\
\hline \multicolumn{9}{|l|}{$\begin{array}{l}\text { Small banking- } \\
\text { sector nations }\end{array}$} \\
\hline Belgium & 150 & 389 & 59.3 & 21.3 & 19.3 & 35.3 & 64.0 & 0.7 \\
\hline Austria & 79 & 297 & 79.7 & 8.9 & 11.4 & 20.3 & 72.2 & 7.6 \\
\hline Sweden & 109 & 106 & 85.3 & 9.2 & 5.5 & 11.0 & 79.8 & 9.2 \\
\hline Norway & 83 & 95 & 74.7 & 15.7 & 9.6 & 10.8 & 80.7 & 8.4 \\
\hline Portugal & 54 & 89 & 51.9 & 20.4 & 27.8 & 27.8 & 29.6 & 42.6 \\
\hline Finland & 48 & 88 & 77.1 & 12.5 & 10.4 & 16.7 & 68.8 & 14.6 \\
\hline Denmark & 100 & 75 & 85.0 & 7.0 & 8.0 & 12.0 & 79.0 & 9.0 \\
\hline Greece & 40 & 47 & 40.0 & 20.0 & 40.0 & 45.0 & 32.5 & 22.5 \\
\hline Ireland & 73 & 26 & 56.2 & 19.2 & 24.7 & 21.9 & 74.0 & 4.1 \\
\hline Luxembourg & 40 & 13 & 15.0 & 17.5 & 67.5 & 27.5 & 57.5 & 15.0 \\
\hline Total & 776 & 1,224 & 67.0 & 14.8 & 18.2 & 21.9 & 67.7 & 10.4 \\
\hline \multicolumn{9}{|l|}{$\begin{array}{r}\text { Former socialist } \\
\text { nations }\end{array}$} \\
\hline Czech Republic & 49 & 43 & 28.6 & 28.6 & 42.9 & 42.9 & 28.6 & 28.6 \\
\hline Poland & 60 & 36 & 28.3 & 26.7 & 45.0 & 50.0 & 21.7 & 28.3 \\
\hline Hungary & 32 & 16 & 18.8 & 43.8 & 37.5 & 40.6 & 40.6 & 18.8 \\
\hline Total & 141 & 96 & 26.2 & 31.2 & 42.6 & 45.4 & 28.4 & 26.2 \\
\hline
\end{tabular}




\section{Table 3: Distribution of Firm Choice of Bank Nationality and Reach, by Home Nation}

This table reports the sample distribution of bank nationality and bank reach according to the nation of the firm's corporate headquarters. Sample firms are foreign affiliates of large multinational companies, while sample banks are those identified by the firms as providing cash management services within each nation. A host nation bank is headquartered in the nation in which the affiliate operates, a home nation bank is headquartered in the same nation as the multinational corporation's headquarters, and a third nation bank is headquartered in neither the host nor the home nation. A global bank provides services to sample firms in at least nine of the 20 European nations and had at least $\$ 100$ billion in worldwide assets as of year-end 1995, a local bank provides services to sample firms only in the European nation of the bank's headquarters and had assets of less than $\$ 100$ billion, and a regional bank is neither global (too few nations or too small) nor local (too many nations or too large).

\begin{tabular}{|c|c|c|c|c|c|c|c|c|}
\hline \multirow[b]{2}{*}{ Nation } & \multirow[b]{2}{*}{$\begin{array}{l}\text { Number } \\
\text { of Firms }\end{array}$} & \multicolumn{4}{|c|}{ Bank Nationality (\%) } & \multicolumn{3}{|c|}{ Bank Reach (\%) } \\
\hline & & $\begin{array}{l}1995 \text { Total } \\
\text { Bank Assets }\end{array}$ & Host & Home & Third & Global & Regional & Local \\
\hline & & (billions \$) & & & & & & \\
\hline ALL FIRMS & 2,118 & & 65.5 & 17.7 & 16.9 & 35.1 & 52.8 & 12.0 \\
\hline \multicolumn{9}{|l|}{$\begin{array}{r}\text { Large banking- } \\
\text { sector nations }\end{array}$} \\
\hline Germany & 177 & 3,041 & 76.8 & 7.9 & 15.3 & 31.6 & 55.4 & 13.0 \\
\hline France & 50 & 1,527 & 60.0 & 26.0 & 14.0 & 32.0 & 54.0 & 14.0 \\
\hline UK & 364 & 1,278 & 79.1 & 6.3 & 14.6 & 30.5 & 57.1 & 12.4 \\
\hline Italy & 84 & 831 & 54.8 & 9.5 & 35.7 & 36.9 & 51.2 & 11.9 \\
\hline Switzerland & 84 & 557 & 63.1 & 3.6 & 33.3 & 48.8 & 40.5 & 10.7 \\
\hline Spain & 12 & 552 & 66.7 & 25.0 & 8.3 & 41.7 & 25.0 & 33.3 \\
\hline Netherlands & 121 & 457 & 47.1 & 26.4 & 26.4 & 48.8 & 45.5 & 5.8 \\
\hline Total & 892 & 8,241 & 69.3 & 10.8 & 20.0 & 35.8 & 52.5 & 11.8 \\
\hline \multicolumn{9}{|l|}{$\begin{array}{l}\text { Small banking- } \\
\text { sector nations }\end{array}$} \\
\hline Belgium & 4 & 389 & 100.0 & 0.0 & 0.0 & 0.0 & 100.0 & 0.0 \\
\hline Austria & 39 & 297 & 64.1 & 28.2 & 7.7 & 17.9 & 51.3 & 30.8 \\
\hline Sweden & 164 & 106 & 73.8 & 12.8 & 13.4 & 21.3 & 67.7 & 11.0 \\
\hline Norway & 65 & 95 & 63.1 & 7.7 & 29.2 & 23.1 & 63.1 & 13.8 \\
\hline Portugal & 12 & 89 & 25.0 & 25.0 & 50.0 & 58.3 & 33.3 & 8.3 \\
\hline Finland & 177 & 88 & 83.1 & 4.5 & 12.4 & 21.5 & 63.8 & 14.7 \\
\hline Denmark & 134 & 75 & 70.1 & 17.9 & 11.9 & 17.2 & 62.7 & 20.1 \\
\hline Greece & 5 & 47 & 40.0 & 20.0 & 40.0 & 80.0 & 20.0 & 0.0 \\
\hline Ireland & 100 & 26 & 58.0 & 9.0 & 33.0 & 43.0 & 47.0 & 10.0 \\
\hline Luxembourg & 16 & 13 & 81.3 & 0.0 & 18.8 & 18.8 & 62.5 & 18.8 \\
\hline Total & 716 & 1,224 & 70.9 & 11.5 & 17.6 & 24.4 & 60.8 & 14.8 \\
\hline \multicolumn{9}{|l|}{$\begin{array}{r}\text { Former socialist } \\
\text { nations }\end{array}$} \\
\hline Czech Republic & 2 & 43 & 100.0 & 0.0 & 0.0 & 0.0 & 50.0 & 50.0 \\
\hline Poland & 2 & 36 & 100.0 & 0.0 & 0.0 & 50.0 & 0.0 & 50.0 \\
\hline Hungary & 0 & 16 & n.a. & n.a. & n.a. & & & \\
\hline Total & 4 & 80 & 100.0 & 0.0 & 0.0 & 25.0 & 25.0 & $\mathbf{5 0 . 0}$ \\
\hline \multicolumn{9}{|l|}{ Other Nations } \\
\hline Japan & 9 & 6,746 & 77.8 & 0.0 & 22.2 & 33.3 & 44.4 & 22.2 \\
\hline US & 470 & 5,012 & 49.1 & 41.7 & 9.1 & 51.1 & 41.7 & 7.2 \\
\hline Canada & 22 & 408 & 72.7 & 0.0 & 27.3 & 18.2 & 59.1 & 22.7 \\
\hline Other & 5 & 422 & 60.0 & 0.0 & 40.0 & 40.0 & 40.0 & 20.0 \\
\hline
\end{tabular}




\section{Table 4: Summary Statistics for the Explanatory Variables}

The table reports summary statistics on host nation characteristics, geographic, cultural, and financial differences between the home and host nations, and attributes of the corporation used as regressors in the two-stage NMNL model of bank nationality and reach decisions. The continuous explanatory variables are specified as the natural logarithm of the variable, denoted by the operator $l n$. The operator $\Delta$ denotes the absolute value of the difference in values between the home and host nations. We show summary statistics with and without the logs, but only the logs are included in the regressions. Former Socialist Nation is a dummy variable equal to one if the host nation is the Czech Republic, Hungary, or Poland, and zero otherwise. Bank Assets/GDP is the aggregate value of a nation's domestic bank assets divided by gross domestic product (GDP). Market Capitalization/GDP is the value of a nation's private sector debt securities and stock market capitalization, divided by GDP. Exports/GDP is the total value of a nation's exports divided by GDP. Bank Assets/GDP, Market Capitalization/GDP, and Exports/GDP are all measured at the end of 1995. Creditor Protection is a dummy variable equal to one when a nation provides strong protection of creditor rights and has a history of strong legal enforcement, and zero otherwise. Distance is the distance, in miles, between the financial centers of the home and host nations. Language Difference is a dummy variable equal to one when a home and host nation do not share an official language, and zero

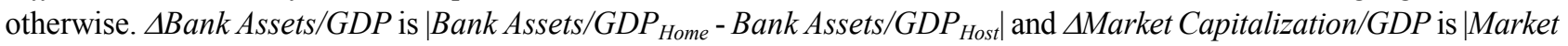
Capitalization $/ G D P_{\text {Home }}$-Market Capitalization/GDP $P_{\text {Host }}$. Simlarly, $\Delta \ln \left(\right.$ Bank Assets/GDP) is $\mid \ln \left(\right.$ Bank Assets/GDP $\left.P_{\text {Home }}\right)$ $\ln \left(\right.$ Bank Assets $\left./ G D P_{\text {Host }}\right) \mid$ and $\Delta \ln ($ Market Capitalization $/ G D P)$ is $\mid \ln \left(\right.$ Market Capitalization/GDP $\left.P_{\text {Home }}\right)-\ln ($ Market Capitalization/GDP $\left.P_{\text {Host }}\right)$. Sales is a corporation's 1995 consolidated sales, based on reported categories in the survey. Number of Nations Doing Business is the number of European nations in which the corporation reports doing business. Relationship Importance is a dummy variable based on the corporation's perceived importance of its banking relationships, equal to one if the response was "important" or "very important," and zero otherwise. Farm and Mining, Manufacturing, and Services \& Trade are dummy variables indicating the broad industry of the corporation, with all other industries excluded from the regressions as the base case. The number of observations is 2,043.

\begin{tabular}{|c|c|c|c|c|c|}
\hline Explanatory Variables & Mean & Median & Minimum & Maximum & Std. Dev. \\
\hline \multicolumn{6}{|l|}{ Host Nation Characteristics } \\
\hline Former Socialist Nation & 0.067 & 0 & 0 & 1 & 0.251 \\
\hline Bank Assets/GDP & 0.971 & 0.994 & 0.287 & 1.810 & 0.379 \\
\hline $\ln ($ Bank Assets/GDP) & -0.123 & -0.005 & -1.245 & 0.593 & 0.464 \\
\hline Market Capitalization/GDP & 1.251 & 1.101 & 0.207 & 1.931 & 0.493 \\
\hline $\ln$ (Market Capitalization/GDP) & 0.119 & 0.097 & -1.574 & 0.658 & 0.506 \\
\hline Exports/GDP & 0.383 & 0.308 & 0.133 & 1.004 & 0.174 \\
\hline $\ln ($ Exports/GDP) & -1.044 & -1.177 & -2.011 & 0.004 & 0.403 \\
\hline Creditor Protection & 0.302 & 0 & 0 & 1 & 0.459 \\
\hline \multicolumn{6}{|l|}{$\begin{array}{r}\text { Differences between Home and Host } \\
\text { Nations }\end{array}$} \\
\hline Distance Between Financial Centers & 1,278 & 894 & 103 & 10,080 & 894 \\
\hline $\ln$ (Distance Between Financial Centers) & 6.750 & 6.796 & 4.650 & 9.218 & 0.947 \\
\hline Language Difference & 0.863 & 1 & 0 & 1 & 0.342 \\
\hline$\Delta$ Bank Assets/GDP & 0.429 & 0.389 & 0.006 & 1.522 & 0.301 \\
\hline$\Delta \ln ($ Bank Assets/GDP) & 0.530 & 0.457 & 0.006 & 20.513 & 1.600 \\
\hline$\Delta$ Market Capitalization/GDP & 0.692 & 0.632 & 0.007 & 2.107 & 0.460 \\
\hline$\Delta \ln ($ Market Capitalization/GDP) & 0.578 & 0.472 & 0.011 & 20.226 & 0.758 \\
\hline \multicolumn{6}{|l|}{ Corporate Attributes } \\
\hline Sales (billions of \$) & 8.964 & 3.501 & 0.050 & 40.000 & 11.036 \\
\hline $\ln ($ Sales, \$) & 8.307 & 8.161 & 3.931 & 10.596 & 1.395 \\
\hline Number of Nations Doing Business & 13 & 13 & 1 & 18 & 5 \\
\hline $\ln ($ Number of Nations Doing Business) & 2.483 & 2.639 & 0.693 & 2.917 & 0.566 \\
\hline Relationship Importance & 0.580 & 1 & 0 & 1 & 0.493 \\
\hline Farming and Mining & 0.109 & 0 & 0 & 1 & 0.311 \\
\hline Manufacturing & 0.469 & 0 & 0 & 1 & 0.499 \\
\hline Services \& Trade & 0.120 & 0 & 0 & 1 & 0.325 \\
\hline
\end{tabular}




\section{Table 5: Regression of Bank Nationality on Host Nation Characteristics, Differences between Home and}

Host Nations, and Imputed Corporate Attributes

This table reports estimated partial derivatives from the two-stage nested multinomial logit (NMNL) regression of bank nationality choice on host nation characteristics, geographic, cultural, and financial differences between the home and host nations, and attributes of the corporation. Each estimated partial derivative measures the change in the probability of observing a given bank nationality choice given a small change in the regressor, holding the other variables constant, evaluated at the sample mean of the explanatory variables, i.e., $(\partial \operatorname{Pr}(N) / \partial Z)_{\bar{Z}}$. A host nation bank is headquartered in the nation in which the affiliate operates, a home nation bank is headquartered in the same nation as the multinational corporation's headquarters, and a third nation bank is headquartered in neither the host nor the home nation. The continuous explanatory variables are specified as the natural logarithm of the variable, denoted by the operator $l n$. The operator $\Delta$ denotes the absolute value of the difference in $l n$ values between home and host nations. Former Socialist Nation is a dummy variable equal to one if the host nation is the Czech Republic, Hungary, or Poland, and zero otherwise. Bank Assets/GDP is the aggregate value of a nation's domestic bank assets divided by gross domestic product (GDP). Market Capitalization/GDP is the value of a nation's private sector debt securities and stock market capitalization, divided by GDP. Exports/GDP is the total value of a nation's exports divided by GDP. Bank Assets/GDP, Market Capitalization/GDP, and Exports/GDP are all measured at the end of 1995. Creditor Protection is a dummy variable equal to one when a nation provides strong protection of creditor rights and has a history of strong legal enforcement, and zero otherwise. Distance is the distance, in miles, between the financial centers of the home and host nations. Language Difference is a dummy variable equal to one when a home and host nation do not share an official language, and zero otherwise. $\Delta \ln ($ Bank Assets/GDP) is $\mid \ln ($ Bank Assets/GDP Home $) \quad-\ln ($ Bank Assets/GDP Host $) \mid$ and $\Delta \ln ($ Market Capitalization/GDP) is $\mid \ln ($ Market Capitalization $\left./ G D P_{\text {Home }}\right)-\ln \left(\right.$ Market Capitalization $\left./ G D P_{\text {Host }}\right) \mid$. Sales is a corporation's 1995 consolidated sales, based on reported categories in the survey. Number of Nations Doing Business is the number of European nations in which the corporation reports doing business. Relationship Importance is a dummy variable based on the corporation's perceived importance of its banking relationships, equal to one if the response was "important" or "very important," and zero otherwise. Farm and Mining, Manufacturing, and Services \& Trade are dummy variables indicating the broad industry of the corporation, with all other industries excluded from the regressions as the base case. The number of observations used in the regressions is 2,043. Standard errors are in parentheses. *, **, *** represent statistical significance at the $10 \%, 5 \%$, and $1 \%$ levels, respectively. 
Table 5

\begin{tabular}{|c|c|c|c|c|c|c|}
\hline & \multicolumn{3}{|c|}{$\begin{array}{c}\text { Estimates of } \partial \operatorname{Pr}(N) / \partial Z_{\bar{z}} \text {. } \\
\text { Dependent variable based on primary } \\
\text { bank only }\end{array}$} & \multicolumn{3}{|c|}{$\begin{array}{c}\text { Estimates of } \partial \operatorname{Pr}(N) / \partial Z_{\bar{z}} \text {. } \\
\text { Dependent variable based on bank with } \\
\text { widest reach }\end{array}$} \\
\hline & Host & Home & Third & Host & Home & Third \\
\hline \multicolumn{7}{|l|}{ Host Nation Characteristics } \\
\hline Former Socialist Nation & $\begin{array}{l}-0.373 * * * \\
(0.087)\end{array}$ & $\begin{array}{c}0.244 * * * \\
(0.030)\end{array}$ & $\begin{array}{c}0.129 * * * \\
(0.033)\end{array}$ & $\begin{array}{c}-0.366^{* * *} \\
(0.083)\end{array}$ & $\begin{array}{c}0.233 * * * \\
(0.064)\end{array}$ & $\begin{array}{c}0.133 * * * \\
(0.033)\end{array}$ \\
\hline Ln(Bank Assets/GDP) & $\begin{array}{l}-0.007 \\
(0.035)\end{array}$ & $\begin{array}{c}0.031 \\
(0.028)\end{array}$ & $\begin{array}{l}-0.024^{*} \\
(0.013)\end{array}$ & $\begin{array}{l}-0.007 \\
(0.033)\end{array}$ & $\begin{array}{c}0.032 \\
(0.025)\end{array}$ & $\begin{array}{l}-0.025^{*} \\
(0.013)\end{array}$ \\
\hline $\ln ($ Market Capitalization/GDP) & $\begin{array}{l}-0.059 \\
(0.046)\end{array}$ & $\begin{array}{c}0.039 \\
(0.037)\end{array}$ & $\begin{array}{c}0.020 \\
(0.018)\end{array}$ & $\begin{array}{l}-0.055 \\
(0.044)\end{array}$ & $\begin{array}{c}0.035 \\
(0.035)\end{array}$ & $\begin{array}{c}0.020 \\
(0.019)\end{array}$ \\
\hline $\ln ($ Exports/GDP) & $\begin{array}{l}0.072^{*} \\
(0.038)\end{array}$ & $\begin{array}{l}-0.052 * \\
(0.029)\end{array}$ & $\begin{array}{l}-0.020 \\
(0.014)\end{array}$ & $\begin{array}{l}0.072 * * \\
(0.036)\end{array}$ & $\begin{array}{l}-0.051^{*} \\
(0.028)\end{array}$ & $\begin{array}{l}-0.020 \\
(0.014)\end{array}$ \\
\hline Creditor Protection & $\begin{array}{l}-0.016 \\
(0.034)\end{array}$ & $\begin{array}{l}-0.001 \\
(0.027)\end{array}$ & $\begin{array}{c}0.015 \\
(0.013)\end{array}$ & $\begin{array}{l}-0.010 \\
(0.032)\end{array}$ & $\begin{array}{l}-0.006 \\
(0.025)\end{array}$ & $\begin{array}{c}0.016 \\
(0.014)\end{array}$ \\
\hline \multicolumn{7}{|l|}{$\begin{array}{r}\text { Differences between Home and } \\
\text { Host Nations }\end{array}$} \\
\hline $\ln ($ Distance $)$ & $\begin{array}{l}-0.065^{* * *} \\
(0.008)\end{array}$ & $\begin{array}{c}0.052^{* * *} \\
(0.007)\end{array}$ & $\begin{array}{c}0.013 * * * \\
(0.003)\end{array}$ & $\begin{array}{l}-0.060 * * * \\
(0.008)\end{array}$ & $\begin{array}{c}0.047 * * * \\
(0.006)\end{array}$ & $\begin{array}{l}0.013 * * * \\
(0.003)\end{array}$ \\
\hline Language Difference & $\begin{array}{l}-0.036 \\
(0.042)\end{array}$ & $\begin{array}{l}-0.035 \\
(0.031)\end{array}$ & $\begin{array}{c}0.071^{* * *} \\
(0.018)\end{array}$ & $\begin{array}{l}-0.034 \\
(0.040)\end{array}$ & $\begin{array}{l}-0.043 \\
(0.030)\end{array}$ & $\begin{array}{c}0.077 * * * \\
(0.019)\end{array}$ \\
\hline$\Delta \ln ($ Bank Assets/GDP) & $\begin{array}{l}-0.047 \\
(0.033)\end{array}$ & $\begin{array}{c}0.011 \\
(0.026)\end{array}$ & $\begin{array}{c}0.036^{* * *} \\
(0.013)\end{array}$ & $\begin{array}{l}-0.032 \\
(0.032)\end{array}$ & $\begin{array}{l}-0.001 \\
(0.025)\end{array}$ & $\begin{array}{c}0.033 * * * \\
(0.012)\end{array}$ \\
\hline$\Delta \ln ($ Market Capitalization/GDP) & $\begin{array}{c}0.027 \\
(0.035)\end{array}$ & $\begin{array}{c}-0.001 \\
(0.028)\end{array}$ & $\begin{array}{c}-0.026^{*} \\
(0.013)\end{array}$ & $\begin{array}{c}0.022 \\
(0.033)\end{array}$ & $\begin{array}{c}0.004 \\
(0.027)\end{array}$ & $\begin{array}{c}-0.026^{* *} \\
(0.013)\end{array}$ \\
\hline \multicolumn{7}{|l|}{ Corporate Attributes } \\
\hline $\ln$ (Sales) & $\begin{array}{c}-0.103 * * * \\
(0.041)\end{array}$ & $\begin{array}{c}0.113 * * * \\
(0.018)\end{array}$ & $\begin{array}{l}-0.010 \\
(0.022)\end{array}$ & $\begin{array}{c}-0.105^{* *} \\
(0.043)\end{array}$ & $\begin{array}{c}0.106^{* * *} \\
(0.018)\end{array}$ & $\begin{array}{l}-0.001 \\
(0.024)\end{array}$ \\
\hline $\begin{array}{r}\ln \text { (Number of Nations Doing } \\
\text { Business) }\end{array}$ & $\begin{array}{l}-0.228^{*} \\
(0.127)\end{array}$ & $\begin{array}{c}0.276^{* * *} \\
(0.054)\end{array}$ & $\begin{array}{l}-0.048 \\
(0.072)\end{array}$ & $\begin{array}{l}-0.227^{*} \\
(0.134)\end{array}$ & $\begin{array}{c}0.289 * * * \\
(0.053)\end{array}$ & $\begin{array}{l}-0.063 \\
(0.080)\end{array}$ \\
\hline Relationship Importance & $\begin{array}{l}-0.004 \\
(0.124)\end{array}$ & $\begin{array}{c}0.016 \\
(0.053)\end{array}$ & $\begin{array}{l}-0.012 \\
(0.071)\end{array}$ & $\begin{array}{l}-0.008 \\
(0.131)\end{array}$ & $\begin{array}{c}0.018 \\
(0.053)\end{array}$ & $\begin{array}{l}-0.010 \\
(0.077)\end{array}$ \\
\hline Farming and Mining & $\begin{array}{l}-0.025 \\
(0.232)\end{array}$ & $\begin{array}{c}0.000 \\
(0.081)\end{array}$ & $\begin{array}{c}0.025 \\
(0.150)\end{array}$ & $\begin{array}{l}-0.061 \\
(0.250)\end{array}$ & $\begin{array}{l}-0.016 \\
(0.080)\end{array}$ & $\begin{array}{c}0.077 \\
(0.169)\end{array}$ \\
\hline Manufacturing & $\begin{array}{l}-0.129 \\
(0.146)\end{array}$ & $\begin{array}{l}0.106^{*} \\
(0.055)\end{array}$ & $\begin{array}{c}0.023 \\
(0.090)\end{array}$ & $\begin{array}{l}-0.132 \\
(0.154)\end{array}$ & $\begin{array}{l}0.104^{*} \\
(0.057)\end{array}$ & $\begin{array}{c}0.028 \\
(0.096)\end{array}$ \\
\hline Services \& Trade & $\begin{array}{l}-0.157 \\
(0.256)\end{array}$ & $\begin{array}{c}0.070 \\
(0.073)\end{array}$ & $\begin{array}{c}0.087 \\
(0.181)\end{array}$ & $\begin{array}{l}-0.158 \\
(0.271)\end{array}$ & $\begin{array}{c}0.058 \\
(0.073)\end{array}$ & $\begin{array}{c}0.100 \\
(0.197)\end{array}$ \\
\hline
\end{tabular}




\section{Table 6: Regressions of Bank Reach on Corporate Attributes}

This table reports estimated partial derivatives from multinomial logit regressions of bank reach on corporate attributes, conditioning first on the choice of bank nationality. Each estimated partial derivative measures the change in probability of observing a given conditional bank reach choice given a small change in a regressor, holding the other variables constant, evaluated at the sample mean of the explanatory variables, i.e., $(\partial \operatorname{Pr}(R \mid N) / \partial Z)_{\bar{Z}}$. A host nation bank is headquartered in the nation in which the affiliate operates, a home nation bank is headquartered in the same nation as the multinational corporation's headquarters, and a third nation bank is headquartered in neither the host nor the home nation. A global bank provides services to sample firms in at least nine of the 20 European nations and had at least $\$ 100$ billion in worldwide assets as of year-end 1995, a local bank provides services to sample firms only in the European nation of the bank's headquarters and had assets of less than $\$ 100$ billion, and a regional bank is neither global (too few nations or too small) nor local (too many nations or too large). The continuous explanatory variables are specified as the natural logarithm of the variable and denoted by the operator $\ln$. Sales is a corporations's 1995 consolidated sales, based on reported categories in the survey. Number of Nations Doing Business is the number of European nations in which the corporation reports doing business. Relationship Importance is a dummy variable based on the corporation's perceived importance of its banking relationships, equal to one if the response was "important" or "very important," and zero otherwise. Farm and Mining, Manufacturing, and Services \& Trade are dummy variables indicating the broad industry of the corporation, with all other industries excluded from the regressions as the base case. The number of observations used in the regressions is 2,043. Standard errors are in parentheses. $*, * *, * * *$ represent statistical significance at the $10 \%, 5 \%$, and $1 \%$ levels, respectively. 
Table 6

\begin{tabular}{|c|c|c|c|c|c|c|}
\hline \multirow{2}{*}{$\begin{array}{r}\text { First-Stage }=\text { Host Nation } \\
\text { Bank } \\
(1350 \text { observations })\end{array}$} & \multicolumn{3}{|c|}{$\begin{array}{c}\text { Estimates of } \partial \operatorname{Pr}(R \mid N) / \partial Z_{\bar{z}} \cdot \\
\text { Dependent variable based on primary } \\
\text { bank only }\end{array}$} & \multicolumn{3}{|c|}{$\begin{array}{c}\text { Estimates of } \partial \operatorname{Pr}(R \mid N) / \partial Z_{\bar{z}} \text {. } \\
\text { Dependent variable based on bank with } \\
\text { widest reach }\end{array}$} \\
\hline & Global & Regional & Local & Global & Regional & Local \\
\hline \multirow[t]{2}{*}{$\ln$ (Sales) } & -0.001 & $0.023 * *$ & $-0.022 * * *$ & -0.000 & 0.009 & -0.009 \\
\hline & $(0.008)$ & $(0.010)$ & $(0.008)$ & $(0.009)$ & $(0.010)$ & $(0.007)$ \\
\hline $\ln$ (Number of Nations Doing & $-0.070 * * *$ & $0.070 * * *$ & 0.000 & $-0.056 * *$ & $0.078 * * *$ & -0.022 \\
\hline Business) & $(0.019)$ & $(0.025)$ & $(0.020)$ & $(0.022)$ & $(0.025)$ & $(0.016)$ \\
\hline \multirow[t]{2}{*}{ Relationship Importance } & 0.020 & 0.008 & -0.028 & 0.016 & 0.014 & -0.030 \\
\hline & $(0.023)$ & $(0.028)$ & $(0.022)$ & $(0.025)$ & $(0.028)$ & $(0.019)$ \\
\hline \multirow[t]{2}{*}{ Farming and Mining } & -0.005 & 0.016 & -0.011 & 0.066 & -0.061 & -0.005 \\
\hline & $(0.039)$ & $(0.048)$ & $(0.038)$ & $(0.042)$ & $(0.048)$ & $(0.031)$ \\
\hline \multirow[t]{2}{*}{ Manufacturing } & 0.008 & 0.009 & -0.018 & 0.044 & -0.003 & $-0.041 * *$ \\
\hline & $(0.025)$ & $(0.031)$ & $(0.024)$ & $(0.028)$ & $(0.031)$ & $(0.020)$ \\
\hline \multirow[t]{2}{*}{ Services \& Trade } & 0.024 & -0.037 & 0.012 & 0.017 & 0.000 & -0.017 \\
\hline & $(0.036)$ & $(0.045)$ & $(0.035)$ & $(0.042)$ & $(0.046)$ & $(0.030)$ \\
\hline \multicolumn{7}{|l|}{$\begin{array}{r}\text { First-Stage }=\text { Home Nation } \\
\text { Bank }\end{array}$} \\
\hline & Global & Reg & & Global & Reg & \\
\hline \multirow[t]{2}{*}{$\ln ($ Sales $)$} & $0.140 * * *$ & $-0.140 * * *$ & & $0.125 * * *$ & $-0.125 * * *$ & \\
\hline & $(0.025)$ & $(0.025)$ & & $(0.024)$ & $(0.024)$ & \\
\hline \multirow{2}{*}{$\begin{array}{r}\ln \text { (Number of Nations Doing } \\
\text { Business) }\end{array}$} & $0.335 * * *$ & $-0.335 * * *$ & & $0.328 * * *$ & $-0.328 * * *$ & \\
\hline & $(0.073)$ & $(0.073)$ & & $(0.070)$ & $(0.070)$ & \\
\hline \multirow[t]{2}{*}{ Relationship Importance } & 0.017 & -0.017 & & 0.018 & -0.018 & \\
\hline & $(0.071)$ & $(0.071)$ & & $(0.068)$ & $(0.068)$ & \\
\hline \multirow[t]{2}{*}{ Farming and Mining } & 0.005 & -0.005 & & -0.001 & 0.001 & \\
\hline & $(0.110)$ & $(0.110)$ & & $(0.104)$ & $(0.104)$ & \\
\hline \multirow[t]{2}{*}{ Manufacturing } & $0.138^{*}$ & $-0.138 *$ & & $0.130 *$ & $-0.130 *$ & \\
\hline & $(0.075)$ & $(0.075)$ & & $(0.073)$ & $(0.073)$ & \\
\hline \multirow[t]{2}{*}{ Services \& Trade } & 0.108 & -0.108 & & 0.090 & -0.090 & \\
\hline & $(0.102)$ & $(0.102)$ & & $(0.097)$ & $(0.097)$ & \\
\hline \multirow{2}{*}{\multicolumn{7}{|c|}{$\begin{array}{r}\text { First-Stage }=\text { Third Nation } \\
\text { Bank }\end{array}$}} \\
\hline & & & & & & \\
\hline (346 observations) & Global & Regional & & Global & Regional & \\
\hline \multirow[t]{2}{*}{$\ln$ (Sales) } & -0.002 & 0.002 & & 0.015 & -0.015 & \\
\hline & $(0.021)$ & $(0.021)$ & & $(0.021)$ & $(0.021)$ & \\
\hline \multirow{2}{*}{$\begin{array}{r}\ln (\text { Number of Nations Doing } \\
\text { Business) }\end{array}$} & -0.054 & 0.054 & & -0.069 & 0.069 & \\
\hline & $(0.049)$ & $(0.049)$ & & $(0.048)$ & $(0.048)$ & \\
\hline \multirow[t]{2}{*}{ Relationship Importance } & -0.022 & 0.022 & & -0.016 & 0.016 & \\
\hline & $(0.054)$ & $(0.054)$ & & $(0.052)$ & $(0.052)$ & \\
\hline \multirow[t]{2}{*}{ Farming and Mining } & 0.052 & -0.052 & & 0.140 & -0.140 & \\
\hline & $(0.092)$ & $(0.092)$ & & $(0.093)$ & $(0.093)$ & \\
\hline \multirow[t]{2}{*}{ Industry } & 0.068 & -0.068 & & 0.068 & -0.068 & \\
\hline & $(0.063)$ & $(0.063)$ & & $(0.061)$ & $(0.061)$ & \\
\hline \multirow[t]{2}{*}{ Services \& Trade } & $0.196 * *$ & $-0.196^{* *}$ & & $0.195 * *$ & $-0.195 * *$ & \\
\hline & $(0.098)$ & $(0.098)$ & & $(0.097)$ & $(0.097)$ & \\
\hline
\end{tabular}




\section{Table 7: Imputed Effects on Unconditional Bank Reach of Host Nation Characteristics, Differences}

between Home and Host Nations, and Corporate Attributes

This table reports imputed partial derivative estimates from the two-stage nested multinomial logit (NMNL) model of host nation characteristics, geographic, cultural, and financial differences between the home and host nations, and attributes of the corporation on bank reach. Each estimated partial derivative measures the change in probability of observing a given bank reach choice given a small change in a regressor, holding the other variables constant, evaluated at the sample mean of the explanatory variables, i.e., $(\partial \operatorname{Pr}(R) / \partial Z)_{\bar{z}}$. A global bank provides services to sample firms in at least nine of the 20

European nations and had at least $\$ 100$ billion in worldwide assets as of year-end 1995 , a local bank provides services to sample firms only in the European nation of the bank's headquarters and had assets of less than $\$ 100$ billion, and a regional bank is neither global (too few nations or too small) nor local (too many nations or too large). The continuous explanatory variables are specified as the natural logarithm of the variable, denoted by the operator $l n$. The operator $\Delta$ denotes the absolute value of the difference in $l n$ values between home and host nations. Former Socialist Nation is a dummy variable equal to one if the host nation is the Czech Republic, Hungary, or Poland, and zero otherwise. Bank Assets/GDP is the aggregate value of a nation's domestic bank assets divided by gross domestic product (GDP). Market Capitalization/GDP is the value of a nation's private sector debt securities and stock market capitalization, divided by GDP. Exports/GDP is the total value of a nation's exports divided by GDP. Bank Assets/GDP, Market Capitalization/GDP, and Exports/GDP are all measured at the end of 1995. Creditor Protection is a dummy variable equal to one when a nation provides strong protection of creditor rights and has a history of strong legal enforcement, and zero otherwise. Distance is the distance, in miles, between the financial centers of the home and host nations. Language Difference is a dummy variable equal to one when a home and host nation do not share an official language, and zero otherwise. $\Delta \ln ($ Bank Assets/GDP) is $\mid \ln ($ Bank Assets/GDP Home $)-\ln ($ Bank Assets/GDP Host $) \mid$ and $\Delta \ln \left(\right.$ Market Capitalization/GDP) is $\mid \ln \left(\right.$ Market Capitalization/GDP $\left.{ }_{\text {Home }}\right)$ $\ln \left(\right.$ Market Capitalization/GDP $\left.P_{\text {Host }}\right)$. Sales is a corporations's 1995 consolidated sales, based on reported categories in the survey. Number of Nations Doing Business is the number of European nations in which the corporation reports doing business. Relationship Importance is a dummy variable based on the corporation's perceived importance of its banking relationships, equal to one if the response was "important" or "very important," and zero otherwise. Farm and Mining, Manufacturing, and Services \& Trade are dummy variables indicating the broad industry of the corporation, with all other industries excluded from the regressions as the base case. The number of observations used in the regressions is 2,043 . Standard errors are in parentheses. ${ }^{*},{ }^{* *},{ }^{* *}$ represent statistical significance at the $10 \%, 5 \%$, and $1 \%$ levels, respectively. 
Table 7

\begin{tabular}{|c|c|c|c|c|c|c|}
\hline & \multicolumn{3}{|c|}{$\begin{array}{c}\text { Estimates of } \partial \operatorname{Pr}(R) / \partial Z_{\bar{z}} \\
\text { Dependent variable based on primary } \\
\text { bank only }\end{array}$} & \multicolumn{3}{|c|}{$\begin{array}{c}\text { Estimates of } \partial \operatorname{Pr}(R) / \partial Z_{\bar{z}} \\
\text { Dependent variable based on bank with } \\
\text { widest reach }\end{array}$} \\
\hline & Global & Regional & Local & Global & Regional & Local \\
\hline \multicolumn{7}{|l|}{ Host Nation Characteristics } \\
\hline Former Socialist Nation & $\begin{array}{c}0.161^{* *} \\
(0.073)\end{array}$ & $\begin{array}{c}-0.093 \\
(0.087)\end{array}$ & $\begin{array}{c}-0.068 * * * \\
(0.016)\end{array}$ & $\begin{array}{l}0.146^{*} \\
(0.078)\end{array}$ & $\begin{array}{l}-0.099 \\
(0.080)\end{array}$ & $\begin{array}{c}-0.047 * * * \\
(0.011)\end{array}$ \\
\hline $\ln$ (Bank Assets/GDP) & 0.003 & -0.002 & -0.001 & 0.003 & -0.002 & -0.001 \\
\hline & $(0.031)$ & $(0.037)$ & $(0.007)$ & $(0.033)$ & $(0.034)$ & $(0.005)$ \\
\hline $\ln ($ Market Capitalization/GDP) & $\begin{array}{c}0.025 \\
(0.041)\end{array}$ & $\begin{array}{l}-0.015 \\
(0.048)\end{array}$ & $\begin{array}{c}-0.012 \\
(0.009)\end{array}$ & $\begin{array}{c}0.022 \\
(0.044)\end{array}$ & $\begin{array}{l}-0.015 \\
(0.045)\end{array}$ & $\begin{array}{l}-0.007 \\
(0.006)\end{array}$ \\
\hline $\ln ($ Exports/GDP) & $\begin{array}{l}-0.031 \\
(0.032)\end{array}$ & $\begin{array}{c}0.018 \\
(0.039)\end{array}$ & $\begin{array}{l}0.013^{*} \\
(0.007)\end{array}$ & $\begin{array}{l}-0.029 \\
(0.035)\end{array}$ & $\begin{array}{c}0.020 \\
(0.036)\end{array}$ & $\begin{array}{l}0.009^{*} \\
(0.005)\end{array}$ \\
\hline Creditor Protection & $\begin{array}{c}0.007 \\
(0.030)\end{array}$ & $\begin{array}{l}-0.004 \\
(0.036)\end{array}$ & $\begin{array}{l}-0.003 \\
(0.007)\end{array}$ & $\begin{array}{c}0.004 \\
(0.032)\end{array}$ & $\begin{array}{l}-0.003 \\
(0.033)\end{array}$ & $\begin{array}{l}-0.001 \\
(0.004)\end{array}$ \\
\hline \multicolumn{7}{|l|}{$\begin{array}{r}\text { Differences between Home and } \\
\text { Host Nations }\end{array}$} \\
\hline $\ln$ (Distance) & $\begin{array}{c}0.028^{* * *} \\
(0.007)\end{array}$ & $\begin{array}{c}-0.016 * * \\
(0.008)\end{array}$ & $\begin{array}{c}-0.012 * * * \\
(0.002)\end{array}$ & $\begin{array}{c}0.024 * * * \\
(0.008)\end{array}$ & $\begin{array}{c}-0.016^{* *} \\
(0.008)\end{array}$ & $\begin{array}{c}-0.008 * * * \\
(0.001)\end{array}$ \\
\hline Language Difference & $\begin{array}{c}0.015 \\
(0.037)\end{array}$ & $\begin{array}{l}-0.009 \\
(0.044)\end{array}$ & $\begin{array}{l}-0.006 \\
(0.008)\end{array}$ & $\begin{array}{c}0.014 \\
(0.040)\end{array}$ & $\begin{array}{l}-0.009 \\
(0.041)\end{array}$ & $\begin{array}{l}-0.005 \\
(0.006)\end{array}$ \\
\hline$\Delta \ln ($ Bank Assets/GDP) & $\begin{array}{c}0.020 \\
(0.029)\end{array}$ & $\begin{array}{l}-0.012 \\
(0.035)\end{array}$ & $\begin{array}{l}-0.008 \\
(0.006)\end{array}$ & $\begin{array}{c}0.013 \\
(0.031)\end{array}$ & $\begin{array}{l}-0.009 \\
(0.032)\end{array}$ & $\begin{array}{l}-0.004 \\
(0.004)\end{array}$ \\
\hline$\Delta \ln ($ Market Capitalization/GDP) & $\begin{array}{l}-0.012 \\
(0.031)\end{array}$ & $\begin{array}{c}0.007 \\
(0.036)\end{array}$ & $\begin{array}{c}0.005 \\
(0.007)\end{array}$ & $\begin{array}{l}-0.009 \\
(0.033)\end{array}$ & $\begin{array}{c}0.006 \\
(0.034)\end{array}$ & $\begin{array}{l}0.003 \\
(0.005)\end{array}$ \\
\hline \multicolumn{7}{|l|}{ Corporate Attributes } \\
\hline $\ln$ (Sales) & $\begin{array}{l}0.067^{*} \\
(0.035)\end{array}$ & $\begin{array}{l}-0.031 \\
(0.054)\end{array}$ & $\begin{array}{c}-0.035 * * * \\
(0.014)\end{array}$ & $\begin{array}{c}0.065 \\
(0.041)\end{array}$ & $\begin{array}{l}-0.045 \\
(0.054)\end{array}$ & $\begin{array}{l}-0.020^{*} \\
(0.011)\end{array}$ \\
\hline $\begin{array}{r}\ln \text { (Number of Nations Doing } \\
\text { Business) }\end{array}$ & $\begin{array}{c}0.098 \\
(0.104)\end{array}$ & $\begin{array}{l}-0.057 \\
(0.161)\end{array}$ & $\begin{array}{l}-0.041 \\
(0.038)\end{array}$ & $\begin{array}{l}0.101 \\
(0.125)\end{array}$ & $\begin{array}{c}-0.055 \\
(0.161)\end{array}$ & $\begin{array}{l}-0.046 \\
(0.029)\end{array}$ \\
\hline Relationship Importance & $\begin{array}{c}0.019 \\
(0.105)\end{array}$ & $\begin{array}{c}0.003 \\
(0.160)\end{array}$ & $\begin{array}{l}-0.022 \\
(0.039)\end{array}$ & $\begin{array}{c}0.017 \\
(0.125)\end{array}$ & $\begin{array}{c}0.006 \\
(0.161)\end{array}$ & $\begin{array}{l}-0.024 \\
(0.031)\end{array}$ \\
\hline Farming and Mining & $\begin{array}{c}0.011 \\
(0.198)\end{array}$ & $\begin{array}{c}0.002 \\
(0.291)\end{array}$ & $\begin{array}{l}-0.013 \\
(0.071)\end{array}$ & $\begin{array}{c}0.085 \\
(0.239)\end{array}$ & $\begin{array}{l}-0.073 \\
(0.297)\end{array}$ & $\begin{array}{l}-0.012 \\
(0.056)\end{array}$ \\
\hline Manufacturing & $\begin{array}{c}0.090 \\
(0.124)\end{array}$ & $\begin{array}{c}-0.053 \\
(0.185)\end{array}$ & $\begin{array}{c}-0.037 \\
(0.045)\end{array}$ & $\begin{array}{c}0.114 \\
(0.147)\end{array}$ & $\begin{array}{l}-0.065 \\
(0.186)\end{array}$ & $\begin{array}{l}-0.048 \\
(0.036)\end{array}$ \\
\hline Services \& Trade & $\begin{array}{c}0.118 \\
(0.216)\end{array}$ & $\begin{array}{c}-0.099 \\
(0.312)\end{array}$ & $\begin{array}{c}-0.019 \\
(0.074)\end{array}$ & $\begin{array}{c}0.106 \\
(0.259)\end{array}$ & $\begin{array}{c}-0.072 \\
(0.315)\end{array}$ & $\begin{array}{c}-0.033 \\
(0.058)\end{array}$ \\
\hline
\end{tabular}

